Research Article, Issue 3
Analytical Methods in Environmental Chemistry Journal
JMECJ

\title{
A Review: Analytical methods for heavy metals determination in environment and human samples
}

\author{
Mojtaba Arjomandi ${ }^{\mathrm{a}, \mathrm{b}}$ and Hamid Shirkhanloo ${ }^{\mathrm{c}, *}$ \\ ${ }^{a}$ Department of Water Sciences and Engineering, Science and Research Branch, Islamic Azad University, Tehran, Iran / Research Institute of \\ Petroleum Industry (RIPI), Tehran, Iran \\ ${ }^{b}$ Department of Geophysics, Geological Survey and Mineral Explorations of Iran (GSI), Tehran, Iran \\ ${ }^{c, *}$ Research Institute of Petroleum Industry, West Entrance Blvd., Olympic Village, P.O. Box: 14857-33111, Tehran, Iran.
}

A R T I C L E I N F O:

Received 14 Jun 2019

Revised form 15 Aug 2019

Accepted 11 Sep 2019

Available online 30 Sep 2019

Keywords:

Heavy metals,

Toxicity,

Biological and Environmental matrix,

Analytical methods,

Nanotechnology

\begin{abstract}
A B S T R A C T
Heavy metals are vital and necessary in our daily lives. Moreover, if the amounts of heavy metals are more than the acceptable amounts (mentioned by WHO) in soil, water, and air, indeed, they cause a lot of diseases in human bodies. Therefore, monitoring and measuring the amounts of heavy metals which are arduous and difficult are so important. In this review paper, a lot of studies which have been carried out on the determination and quantification of heavy metals in human bodies, soil, and water are considered. Moreover, the effect of toxicity of each heavy metal on human health is assessed. According to WHO, EPA, NIOSH, ACGIH, and clinical chemistry, determination of heavy metals such as $\mathrm{Cd}, \mathrm{Pb}, \mathrm{Zn}, \mathrm{Hg}, \mathrm{Cu}, \mathrm{Mn}$ is very important in human body and Environmental matrixes. For example, the range concentration of heavy metals in human body such as, cadmium is about 0.3 to 0.98 , and for cooper, it is about $0.01-1.107 \mathrm{ppm}$. In addition, most obtained results demonstrate that the lowest and highest range concentration of heavy metals in blood of human body has been equal to $0.56-8.78 \mathrm{ppm}$ and $0.08-4.67 \mathrm{ppm}$ respectively. Finally, in this review paper, the approaches of quantification of heavy metals using atomic absorption spectrometry, gas chromatography, inductively coupled plasma mass spectrometry etc. in human bodies, water, and soil are assessed.
\end{abstract}

\section{Introduction}

Many different techniques have been applied for determination of heavy metal in different samples. Atomic absorption spectrometry (AAS) is a quantitative method of metals analysis which was suitable for the determination of 70 elements by three option accessory (flame, furnace, Hydride generation). AAS measures the concentration of the metals by passing light (wave length emitted) by a radiation source of

\footnotetext{
*Corresponding Author: Hamid Shirkhanloo

E-mail: Hamidshirkhanloo@yahoo.ca; iranma4@gmail.com https://doi.org/10.24200/amecj.v2.i03.73
}

a particular element such as $\mathrm{Hg}, \mathrm{As}, \mathrm{Pb}$ and etc. Many metals determined by electrothermal atomic absorption spectrometry (ET-AAS) [1-9], flame atomic absorption spectrometry (F-AAS and FS-AAS) [10-18], atom trapping flame atomic absorption spectrometry (AT-FAAS), Hydride generation atomic absorption spectrometry, Cold vapor-atomic absorption spectrometry (HG-AAS, CV-AAS) $[19,20]$ and fluorescence spectrometry (XRF) [21-24]. Also, direct current polarography (DCP) $[25,26]$, differential pulse polarography (DPP), neutron activation analysis (NAA), inductively coupled plasma-optical emission spectrometry (ICP OES) [27, 28], inductively 
coupled plasma- mass spectrometry (ICP-MS) [29, 30], UV-VIS [31], HPLC-inductively coupled plasma-mass spectrometry (HPLC - ICP - MS) [32], electrophoresis(EP) [33], Anodic striping voltammetry (AVS) and inductively coupled plasma-mass spectrometry (ICP-MS) was used for heavy metal determination in different matrix [34, 35]. Arida et al showed that the assessment of heavy and toxic metals in the blood and hair by modern analytical techniques in review paper. Heavy metals and toxic metal effect in blood and hair of some smokers was determined by modern analytical techniques. The levels of $\mathrm{Hg}, \mathrm{Pb}, \mathrm{Cd}, \mathrm{As}, \mathrm{Se}, \mathrm{Mn}$, $\mathrm{Zn}, \mathrm{Ni}$, and $\mathrm{Cr}$ were determined using inductively coupled plasma-atomic emission spectrometer (ICP-AES) [36]. A review procedure based on heavy metal analyzing in soil was developed with sequential extraction by Zimmerman et al in 2010 . They showed that the quantification extraction and determination of heavy contamination in soil cannot give reliable results. They showed, the procedures of community bureau of reference (BCR) and geological society of Canada (GCS) procedures were examined to clarify benefits and limitations of each [37]. Also, determination of heavy metal in blood evaluated with AAS by Batool and Ahmad at 2018. The blood samples were divided into two parts .First for analysis of total blood and other for serum. By centrifuging the blood and serum sample separated. Serum after adding de ionized water analyzed by instrument after digestion. For whole blood samples wet digestion apply before analysis. Before analysis, blood samples were kept in freezer at $4{ }^{\circ} \mathrm{C}$. In this study, wet digestion includes decomposition by acids carried out on hotplate and continued by AAS model Varian AA 240 [38]. Yuan $\mathrm{Fu}$ et al used Titanate $/ \mathrm{TiO}_{2}$ as adsorption sorbent for heavy metals determination and adsorption by nanotechnology. The titanate/TiO2 Nanomaterials were synthesized by Biomolecules (lignin). The titanate $/ \mathrm{TiO}_{2}$ characterized by XRD, FESEM, TEM, FTIR and BET, and their adsorption for heavy metals were studied. The found the maximum adsorption capacity of heavy metal ions $\left(\mathrm{Pb}^{2+}, \mathrm{Cu}^{2+}, \mathrm{Cd}^{2+}\right)$ based on procedure
[39]. Zhang et al showed, the nanomaterials can be treatment in water and wastewater samples. They introduce a novel nanotehecnology which was used by researcher included, the synthesis and physiochemical properties of nanomaterials, carbon based nanomaterial, metal and metal oxides nanoparticles were focused on removal of various heavy metals in water and wastewater [40]. Chromium speciation in natural water samples was developed by solid phase extraction procedure. $\mathrm{Cr}(\mathrm{VI})$ can be extracted with ammonium pyrrolidine dithiocarbamate (APDC) pasted on multi walled carbon nanotubes (MWNTs). The total chromium was determined by oxidation of $\mathrm{Cr}(\mathrm{III})$ to $\mathrm{Cr}(\mathrm{VI})$. The $\mathrm{Cr}(\mathrm{III})$ concentration is calculated by subtracting of total chromium and $\mathrm{Cr}$ (VI) [41]. Cr (VI) compounds, once inside the bloodstream, are actively transported into red blood cells (RBC) via nonspecific anionic channels and then rapidly reduced to $\mathrm{Cr}$ (III) which becomes bound to hemoglobin. As canceroginic effect of $\mathrm{Cr}$ (VI) determination of $\mathrm{Cr}$ (VI) very important. Also, in Figure 1, metabolism and formation of DNA damage by $\mathrm{CrVI}$ at $\mathrm{pH} 7.4$ are shown.

Zendehdel et al studied on a $\mathrm{HAp} / \mathrm{NaP}$ nanocomposite by adding a synthesized nanohydroxyapatite to zeolite NaP gel. They used HAp/ $\mathrm{NaP}$ for the removal of lead(II) and cadmium(II) ions from aqueous solution. This nanocomposite was characterized by FTIR, X-ray, SEM, energydispersive X-ray analysis and thermal analyses [42]. Microwave-assisted method was used for synthesizing of graphenenanosheet/ $\delta$ - $\mathrm{MnO}_{2}$ (GNS/ $\mathrm{MnO}_{2}$ ) composite. TheGNS/MnO as sorbent was used for removal of NI(II) from waters. SEM, TEM and FTIR show that nanoscale $\delta-\mathrm{MnO}_{2}$ deposit well on GNS. The adsorption process was achieved in optimized $\mathrm{pH}$ [43]. Ojea-Jiménez et al showed that the removal of mercury from the Ebro River by Colloidal gold nanoparticles (Au NPs). Au NPs have been used for sequestration removal of $\mathrm{Hg}$ (II) from multicomponent waters. Under optimized conditions, sodium citrate was reduced Au NPs as the catalyst in the reduction of $\mathrm{Hg}$ (II), which is efficiently trapped in the presence of $\mathrm{Cu}(\mathrm{II})$ and 

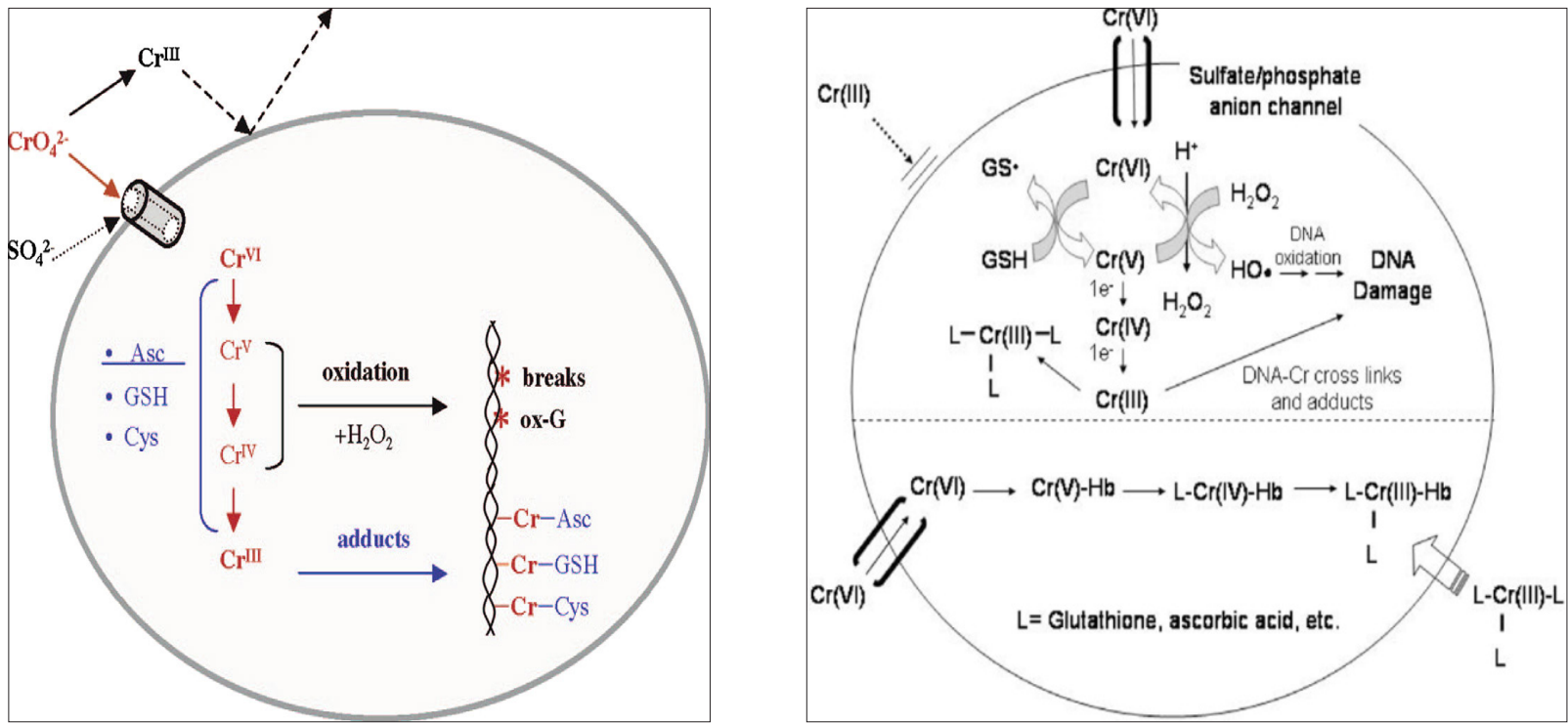

Fig. 1. Metabolism, and formation of DNA damage by $\mathrm{Cr}(\mathrm{VI})$ at $\mathrm{pH}$ 7.4.

Fe(III) [44]. Many references existed for separation and preconcentration and determination based on LLME, SPE, MSPE, IL/MSPE, USA-MSPE etc. in water, human biological and food samples by nanotechnology [45-56]. Also many developed methods was reported by researchers by green solvents such as ionic liquid for extraction of heavy metals in different matrixes [57-88]. In addition, an advanced approach for separating $\mathrm{As}(\mathrm{III})$ and $\mathrm{As}(\mathrm{V})$ ions in environmental matrixes was presented by Soylak et al in 2009 [89]. In their research, when dilute $\mathrm{KMnO}_{4}$ was used to oxidize $\mathrm{As}(\mathrm{III})$, then the developed coprecipitation was used to determine total arsenic [89]. The difference between the total arsenic content and $\mathrm{As}(\mathrm{V})$ content was calculated as Arsenic(III) [89]. Moreover, in their study, hydride generation atomic absorption spectrometry (HGAAS) was used to determine arsenic levels. Also, after calculating the factor of preconcentration, it was found out that the factor was equal to 25 . In addition, the detection limits (LOD) for $\mathrm{As}(\mathrm{V})$ was $0.012 \mu \mathrm{g} . \mathrm{L}^{-1}$ [89]. A new approach for solid phase extraction (SPE) of gold(III) by using Dowex M 4195 chelating resin was developed by Soylak et al in 2007 [90]. The quantitative sorption of gold $^{3+}$, effect of flow rates, $\mathrm{pH}$, sorption capacity, eluent types, and the effect of diverse ions on the sorption of $\mathrm{Au}^{3+}$ were investigated to find optimum experimental conditions [55]. In their work, for more than 100 cycles of sorption-desorption, the chelating resin was reused without any considerable change in sorption of $\mathrm{Au}^{3+}$ [90]. In their work, the preconcentration factor was calculated to be 31. Detection limit (LOD) of $\mathrm{Au}$ was greater than $1.60 \mu \mathrm{g} \mathrm{L}^{-1}$ and the recovery values for $\mathrm{Au}^{3+}$ was greater than $96 \%$ [90]. The adsorption capacity of the resin was $8.1 \mathrm{mg} \cdot \mathrm{g}^{-1}$. Their proposed approach has been determining $\mathrm{Au}^{3+}$ in some real soil and water samples were used and showed the best results [90]. For characterizing As(III) biosorption from aqueous solution, green algae (Ulothrix cylindricum) biomass was used by Soylak et al in 2009 [91]. According to their studies, the biosorption capacity of Ulothrix cylindricum biomass was equal to $67.2 \mathrm{mg} \mathrm{g}^{-1}$ [91]. The outcomes of their work indicated that the processes of biosorption of $\mathrm{As}^{3+}$ followed well pseudo-second-order kinetics [91]. Separation of $\mathrm{Cu}^{2+}$ in environmental matrixes by using solid phase extraction on multi-walled CNT (carbon nanotubes) was studied by Soylak and Ercan in 2009 [92]. The optimum adsorption was obtained on MWNTs column in their study when $\mathrm{pH}$ was equal to 7.0. The preconcentration factor was equal to 60 . Also, the detection limit for $\mathrm{Cu}^{2+}$ was equal to $1.46 \mu \mathrm{g} \mathrm{L}^{-1}$ [92]. For atomic absorption spectrometry, separation of trace heavy metals in sediment, urine, and dialysis concentrates by coprecipitation with samarium hydroxide was 
carried out by Elci et al in 2003 [93]. In their study, the optimum $\mathrm{pH}$ for collecting trace heavy metals on samarium hydroxide was equal to 12.2. Also, coprecipitation occurs after 30 minutes, and when quantitative recovery is governed, and the precision is about $5 \%$ for the analytes [93]. Determining heavy Metals in plants, soil, and groundwater which followed high-rate sewage sludge was studied by Speir et al in 2003 [94].The $\mathrm{pH}$ of samples was less than 4 . Also, during five years, the concentration of $\mathrm{Zn}$ in the soil reduced from $27 \mathrm{mg} \mathrm{kg}^{-1}$ to $0.04 \mathrm{mg} \mathrm{kg}^{-1}$. Moreover, based on their study, there is a direct relation between the concentration of heavy metals in plants and the concentration of heavy metals in the soil [94]. An advanced biological treatment plant for removing heavy metals in groundwater was presented by Scheeren et al in 2007. Groundwater below the zinc production plant was contaminated with sulphate and heavy metals. To avoid contamination of nearby drinking-water aquifers in the future, a treatment plant for extracting contaminated ground water was established by them [95]. Effluent treatment based on activity of Sulphate Reducing Bacteria (SRB) for excess sulphide in solids for achieving the discharge criteria was designed by them. The reducing the sulphate to sulphide and thereby, precipitation of metal sulphides were obtained when anaerobic bacteria are there in the soil or the bacteria are injected [95].

Determination of trace heavy metals in harvested rainwater by ICP-MS was used by Malassa et al in 2018 [96]. Inductively coupled plasma mass spectrometry (ICP-MS) was used to quantify the content of each trace heavy metal $(\mathrm{Cr}$, $\mathrm{Co}, \mathrm{Mn}, \mathrm{Ni}, \mathrm{Cu}, \mathrm{Zn}, \mathrm{Mo}, \mathrm{Ag}, \mathrm{Cd}, \mathrm{Bi}$, and $\mathrm{Pb}$ ) in a few rainwater samples. Their results indicated that that the concentrations of $\mathrm{Cr}, \mathrm{Mn}, \mathrm{Ni}, \mathrm{Ag}$, and $\mathrm{Pb}$ are more than the WHO limits in drinking water [96]. Contamination of heavy metals in sediments of the Karasu spring in Nigde, Turkey has been investigated by Yalcin and Narin in 2007 [97]. A few sediment matrixes were collected from contaminant sites along the spring. Moreover, concentrations of heavy metals have been determined by X-ray Fluorescence Spectrometer [97]. The amount of $\mathrm{Co}, \mathrm{Cu}, \mathrm{As}, \mathrm{Sn}, \mathrm{Ni}, \mathrm{Zn}, \mathrm{Ca}$, $\mathrm{Pb}, \mathrm{Al}, \mathrm{Fe}, \mathrm{Ti}, \mathrm{Cr}$, and $\mathrm{Mn}$ contents of the Karasu creek sediments were equal to 18.30-69.00, 12.40-595.0 5.50-345.3, 5.80-15.1, 10.9-64.1, 28.90-103,300, 4.1-356.2, 7.70-37,840, 13,460 $109,400,11,740-62,900,22.18-59.04,41.70-369$ and $12.09-3,480 \mathrm{mg} / \mathrm{kg}$ respectively. Moreover, according to their results, the presence of a contamination in the Karasu creek is obvious. In the case study, all the metal concentrations are more than acceptable limit values. In addition, in the Karasu creek and the Akkaya dam, eutrophication has been being developed. Also, it sounds that the accumulation of heavy metal in the creek is come from the discharge of mine quarries, domestic, and industrial wastes [97]. Separation of arsenic(III) and arsenic(V) by using Streptococcus pyogenes which has been immobilized on Sepabeads SP 70 resin has been considered by the approach of solidphase extraction by Uluozlu et al in 2010 [98]. In sample solutions, hydride generation atomic absorption spectrometry (HGAAS) has been used to quantify the arsenic levels [98]. Their procedure has been governed when recovery of $\mathrm{As}^{3+}$ was more than $95 \%$. Moreover, recovery of $\mathrm{As}^{5+}$ which was obtained was less than 5\%. By using KI and ascorbic acid, $\mathrm{As}(\mathrm{V})$ has been reduced; in addition, after 1 hour later, for determining total arsenic, their system has been applied. $\mathrm{As}^{5+}$ has been calculated by subtracting the total As from As(III) content $[98,99]$. Some experimental parameters such as $\mathrm{pH}$, amount of microorganism, sample volume have been assessed in their study. The capacity of biosorbent for $\mathrm{As}^{3+}$ has been equal to $7.3 \mathrm{mg} \mathrm{g}^{-1}$. The preconcentration factor has been found to be equal to 36 [99]. The relative standard deviation has been obtained less than $8 \%$ [99]. Moreover, the contamination of trace heavy metal ions in drinking water samples has been investigated by Tuzen et al in 2005. According to their studies, if the amount of lead in drinking water samples is more than 10 microgram per liter, brain tissues and kidneys will be damaged [100]. Assessment of the amount of each metal in Drinking Waters from the 
Tokat-Black Sea Region of Turkey was studied by Tuzen and Soylak in 2006. In their study, atomic absorption spectrometry was used to determine the amount of $\mathrm{Cr}, \mathrm{Ni}, \mathrm{Cu}, \mathrm{Mn}, \mathrm{Zn}, \mathrm{Fe}, \mathrm{Co}$, and $\mathrm{Al}$ ions. According to their study, the amount of the heavy metals was lower than the maximum acceptable limits which were set by the World Health Organization [101-138]. In this review paper, the amounts of heavy metals and their toxicity in water, soil, air, and human bodies which have been studied and quantified by other researchers during the last decade are considered.

\section{Experimental}

Kaipei Qiu used ultrafine mesoporous magnetite nanoparticles (UFMNPs) for removal of heavy metals from waters (Scheme 1). Ultrafine magnetite $\mathrm{NPs}\left(\mathrm{UFMNPs}, \mathrm{Fe}_{3} \mathrm{O}_{4}\right)$ were synthesized by coprecipitation method and successfully used as adsorbents for the removal of $\mathrm{Pb}^{2+}, \mathrm{Cd}^{2+}, \mathrm{Cu}^{2+}$, and $\mathrm{Ni}^{2+}$ ions from contaminated river water. Also, the adsorption/desorption tests demonstrated that the ultrafine $\mathrm{Fe}_{3} \mathrm{O}_{4}$ NPs were reusable and can be used several times [139].

Gollavelli et al and Luo et al used Magnetic Graphene and magnetic chitosan/cellulose microspheres for removal of heavy metal from dinking waters, waters [140,141]. Mahmoudi ,Chen and Neyaz can be extracted heavy metals from different matrix by iron oxide nanoparticles (SPIONs), $\mathrm{Fe}_{3} \mathrm{O}_{4} @ \mathrm{SiO}_{2}$ and functionalized iron oxide nanomaterials [142-144]. Tuzen et al showed a novel method based on switchable hydrophilicity microextraction syringe system ( $\mu \mathrm{S}-\mathrm{SHS}$ ) by electrothermal atomic absorption spectroscopy (ETAAS). The proposed method was developed for separation and determination of vanadium in waters by complexing 2-(5-Bromo-2-pyridylazo)5-diethylaminophenol (5- Br-PADAP). In this study, LOD, EF, and RSD were achieved $7.5 \mathrm{ng}$ $\mathrm{L}^{-1}, 120$ and $2.91 \%$, respectively. In addition, the $\mu \mathrm{S}-\mathrm{SHS}$ is consisting of micropipette tip and syringe system was designed. First, the $10 \mathrm{~mL}$ of real sample was placed on beaker and then, 5- BrPADAP solutions as ligand were used by sucking into syringe system. Finally, $0.1 \mathrm{~mL}$ of decanoic acid as a hydrophobic effect sucked into to solution which was followed by $500 \mu \mathrm{L}$ of $1.0 \mathrm{~mol} \mathrm{~L}-1$ $\mathrm{Na}_{2} \mathrm{CO}_{3}$ solution as a switchable hydrophobicity for the decanoic acid $\left(\mathrm{CH}_{3}\left(\mathrm{CH}_{2}\right)_{8} \mathrm{COOH}\right)$ in liquid phase. The surface response methodology was used to calculate response surface between $[\mathrm{pH}] /[\mathrm{V}$ of SHS $]$ and $[\mathrm{pH}] /\left[\mathrm{V}\right.$ of $\left.\mathrm{Na}_{2} \mathrm{CO}_{3}\right]$ of the vanadium. The results showed, high recovery based on 112 $\mu \mathrm{L}$ of SHS and $624 \mu \mathrm{L}$ of $\mathrm{Na}_{2} \mathrm{CO}_{3}$ was obtained at $\mathrm{pH}=3.28$. The design of experiments (DOE) was used for analyzing data and optimizing by surface response methodology [102]. Xiaogang Luo et al explained a novel sorbent for absorption heavy metals from waters. The carboxyl decorated magnetite $\left(\mathrm{Fe}_{3} \mathrm{O}_{4}\right)$ nanoparticles (MN-CA) were obtained by modifying the magnetite surface with

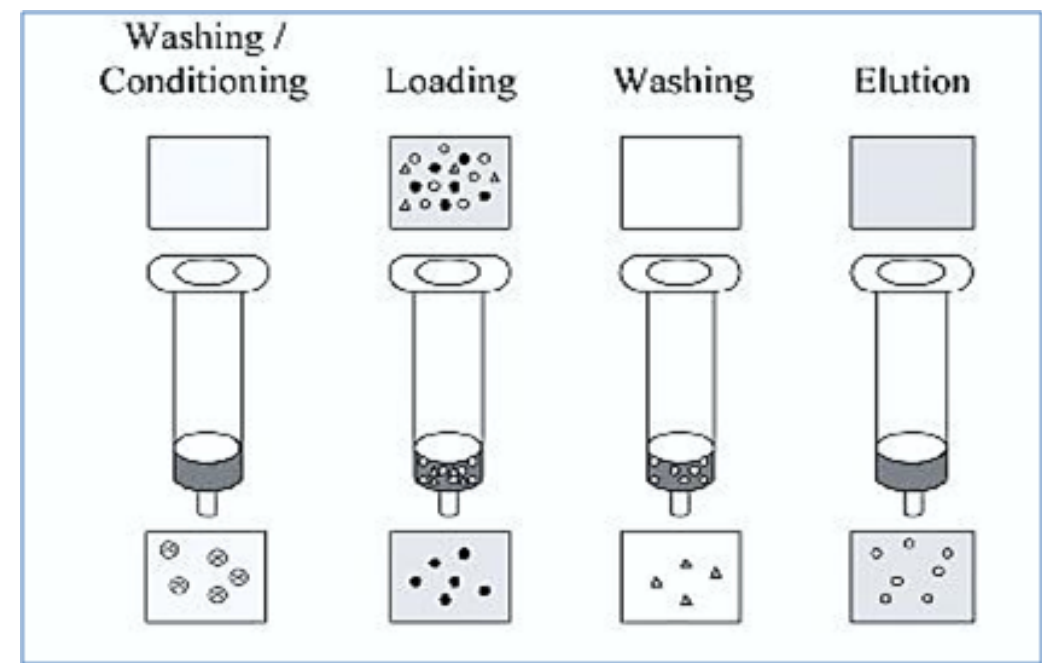

Scheme 1. SPE method for extraction heavy metals from liquids 
citric acid. .In this research, the combination of specifically modified magnetic nanoparticles and activated carbon(AC) to cellulose may create new nanocomposite adsorbents, which possess high adsorption capacity for heavy metals removal and easy recovery by magnetic field. It could be deduced that electrostatic attraction between negatively charged magnetic cellulose-based beads (MCB) samples and positively charged $\mathrm{Cu}^{2+}, \mathrm{Pb}^{2+}$, and $\mathrm{Zn}^{2+}$ was the initial driving force of heavy metals binding to the adsorption site of the adsorbents [145]. Researcher such as Shannon, Luo, Gericke, Karami and Zhao et al worked for removal heavy metals from water, water Purification, wastewater treatment and methyl orange removal by novel technique with different sorbents such as; activated magnetic cellulose Microspheres, functional cellulose beads, magnetite nanoparticles, and hierarchical MWCNTs $/ \mathrm{Fe}^{3} \mathrm{O}_{4} / \mathrm{PANI}$ magnetic composite [146-150]. For determining the amount of metals in drinking water samples, the Perkin Elmer Analyst 700 atomic absorption spectrometer was used by Tuzen and Soylak in 2006 [101]. A $10 \mathrm{~cm}$ long slot-burner head, a lamp and an airacetylene flame were applied. In solid phase extraction (SPE) studies, a glass column with 100 $\mathrm{mm}$ high and $10 \mathrm{~mm}$ in diameter was applied [101]. The solid phase materials such as Amberlite XAD1180, Amberlite XAD-4 and Diaion HP-2MG was purchased, and they were prepared with the washing steps as reported previously in literature. They collected the drinking water samples in prewashed (with detergent, doubly de-ionized distilled water, diluted $\mathrm{HNO}_{3}$ and doubly de-ionized distilled water, respectively) polyethylene bottles from eight stations in Tokat and villages around Tokat in July 2004. The samples were obtained from the water pump directly after the water had run for at least twenty minutes. They filtered the samples by using a Millipore cellulose membrane with a $0.45 \mu \mathrm{m}$ pore diameters [101]. After the process of filtration, nitric acid was used to acidify the samples to $1 \%$, and then the samples were stored in $1 \mathrm{~L}$ polyethylene bottles. The samples were thereby stored at $4{ }^{\circ} \mathrm{C}$ for a short time, afterwards they were analyzed until the changes of the physicochemical form of the metals were minimized [101]. Electroplating industry, tanneries, electronics manufacturing industry, coalfired power plants and mining operation are key sources of heavy metal pollution in water [151]. Lead $(\mathrm{Pb})$ is discharged into water sources from various industries and is highly toxic to human beings even at trace concentrations. Maximum contaminant level of $\mathrm{Pb}$ (II) in drinking water is set at $15 \mu \mathrm{g} \mathrm{L}-1$ by US Environmental Potential Agency (US EPA). Chromium(Cr), another toxic heavy metal pollutant, is mainly present in the effluents of leather tanning, electroplating and chromate preparations. Chromium is found in two oxidation states $\mathrm{Cr}(\mathrm{III}, \mathrm{VI})$ and $\mathrm{Cr}(\mathrm{VI})$ is more toxic. World Health Organization (WHO) guideline for $\mathrm{Cr}(\mathrm{VI})$ in drinking water is $50 \mu \mathrm{g} \mathrm{L}^{-1}$. So determination and separation this pollutant from waters with novel technique based on sorbent adsorption is very important [151]. Santhosh et al showed lead and $\mathrm{Cr}$ simply extracted from water solutions by PG-C and CNF-C [151]. By using thermal process, cobalt ferrites $\left(\mathrm{CoFe}_{2} \mathrm{O}_{4}\right)$ paste on porous graphene (PG) and carbon nanofibers (CNF)), which was named PG-C and CNF-C nanocomposites as magnetic adsorbents [151]. In Figure 2, removal of heavy metals using nanographene is shown.

Sarika Singh et al used a functional oxide nanomaterials and nanocomposites for the removal of heavy metals and dyes in liquid phase. They showed that the oxide-based nanomaterials, such as $\mathrm{Fe}_{3} \mathrm{O}_{4}, \mathrm{ZnO}$ and $\mathrm{TiO}_{2}$ for the removal of different toxic metals and organic dyes at optimized $\mathrm{pH}$. Magnetic nanoparticles as excellent sorbent can be used as highly effective, efficient and economicallyviable for removal toxic metals with advantages of easy separation under a magnetic field for reuse. Shen et al have observed that the adsorption efficiency of $\mathrm{Ni}^{2+}, \mathrm{Cu}^{2+}, \mathrm{Cd}^{2+}$ and $\mathrm{Cr}^{6+}$ ions by $\mathrm{Fe}_{3} \mathrm{O}_{4}$ nanoparticles is strongly dependent on $\mathrm{pH}$, temperature, and the amount of the adsorbent. In optimized conditions, $3.5 \mathrm{mg} \mathrm{mL}^{-1}$ dose of nanoadsorbent with an optimum $\mathrm{pH}=4$ was used for removal heavy metals from contaminated water [152]. Phoebe Zito Ray et al studied on Inorganic 


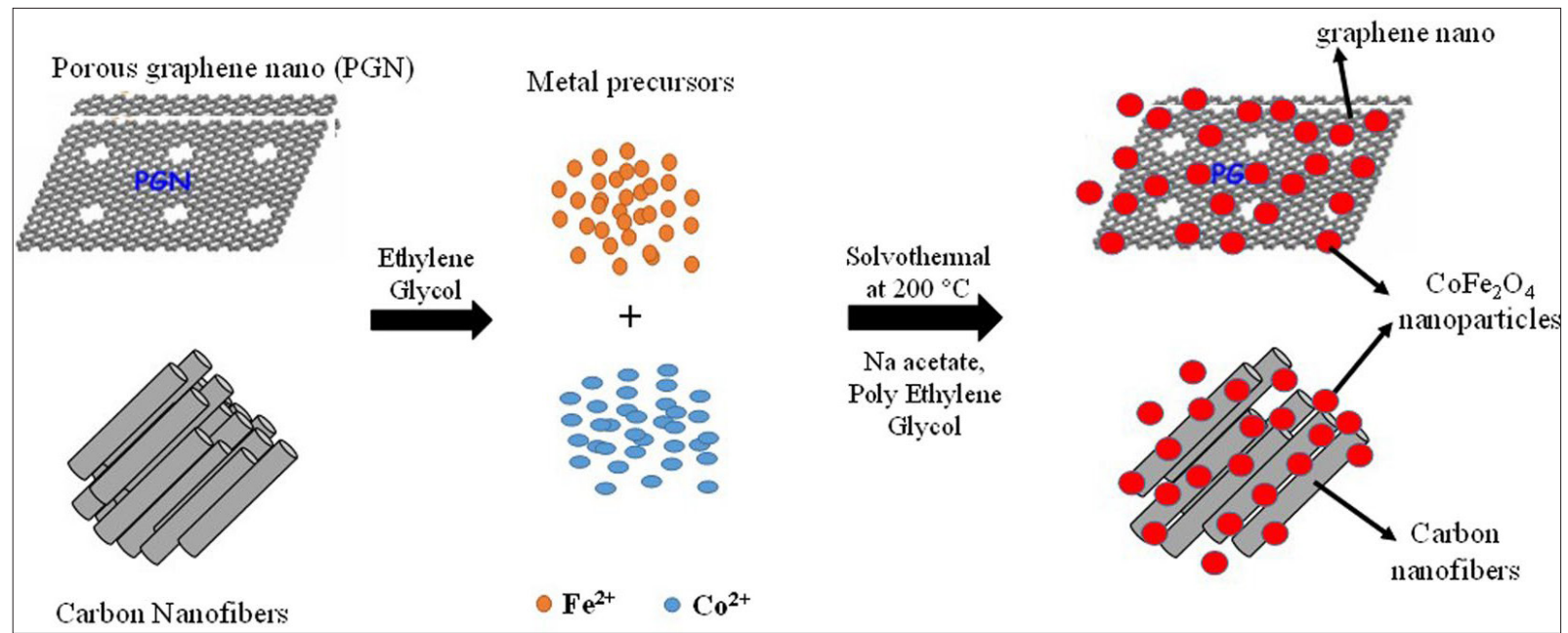

Fig. 2. Removal of heavy metals using nano-graphene [151].

nano-adsorbents for the removal of heavy metals and arsenic in aqueous solutions. They were explained that metal oxides and CNTs as nanoadsorbents were used for heavy metal removal in aqueous solutions. Phoebe Zito Ray et al used the iron oxide (hematite, magnetite and maghemite), carbon nanotubes (CNT), and metal oxide based ( $\mathrm{Ti}, \mathrm{Zn}$ ) and polymeric nanoadsorbents for this study. Based on reults, metal oxides can have increased surface area and possess favorable sorption to heavy metals. $\mathrm{ZnO}$ nanoplates showed complete removal of $\mathrm{Cu}^{2+}$ in aqueous solutions [153]. Recently, CNTs and nZVI synthetized by coupling these nanomaterials and was efficient used for removal of $\mathrm{Cr}(\mathrm{VI})$, Se and Co from polluted water by Giorgio Vilardi et al. Regeneration studies were performed fixing CNTs-nZVI concentration and the initial metal concentration equal to $10 \mathrm{mg} \mathrm{L}^{-1}$, as already reported in a previous study [154]. Experimental results of adsorption batch tests showed that the removal efficiency of nanomaterials was in decreasing order: CNTnZVI $>$ nZVI $>$ CNTs $>$ CNTs-nZVI, except for the $\mathrm{Cr}(\mathrm{VI})$ that nZVI was the most efficient material. Furthermore, the removal of $\mathrm{Cr}(\mathrm{VI})$ was found to not be affected by varying the $\mathrm{pH}$ in the case of using nZVI, but decreased with increasing $\mathrm{pH}$ when using the other three nanomaterials [154]. Also, Majed Alrobaian and Hassan Arida studied on Assessment of Heavy and Toxic Metals in the Blood and Hair of Saudi Arabia Smokers Using Modern Analytical Techniques. The levels of some selected heavy and toxic metals (e.g.; $\mathrm{Hg}, \mathrm{Pb}$, $\mathrm{Cd}, \mathrm{As}, \mathrm{Se}, \mathrm{Mn}, \mathrm{Zn}, \mathrm{Ni}$, and $\mathrm{Cr}$ ) were determined using inductively coupled plasma-atomic emission spectrometer (ICP-AES). Prior to the analysis, the blood and hair samples of Saudi Arabia smokers were collected, treated, and digested by microwave digestion system. The validation measurement of ICP-AES was performed using working calibration solutions of the investigated toxic heavy metal ions $(\mathrm{Hg}, \mathrm{Pb}, \mathrm{Cd}, \mathrm{As}, \mathrm{Se}, \mathrm{Mn}, \mathrm{Zn}, \mathrm{Ni}$, and $\mathrm{Cr}$ ) [155]. Kaiser, Zheng and Feng was introduced a novel two-dimensional polymers synthesis with nano size in water which was different application such as heavy metal removal. They reported the controlled synthesis of few-layer two-dimensional polyimide crystals on the surface of water through reaction between amine and anhydride monomers, assisted by surfactant monolayers [156]. Heavy metals such a lead or cadmium has devastating health effects on human body. So, removal of heavy metals from industrial wastewater and drinking water is very important. Rosillo-Lopez et al showed that carboxylated graphene nanoflakes (cx-GNF) and nano-graphene oxide (nGO) can be extracted $\mathrm{Fe}^{2+}$, $\mathrm{Cu}^{2+}, \mathrm{Fe}^{3+}, \mathrm{Cd}^{2+}$ and $\mathrm{Pb}^{2+}$ ions from water sample. The sorption capacity for $\mathrm{Pb}^{2+}$, is more than six times greater for the cx-GNF compared to GO which is attributed to the efficient formation of lead carboxylates as well as strong cation $-\pi$ interactions [157]. Zhao et al introduced a novel multithroughput dynamic microwave-assisted leaching 
(MDMAL) combined with ICP-AES was used for the simultaneous determination of $\mathrm{Cu}, \mathrm{Mn}, \mathrm{Zn}$ and $\mathrm{Pb}$ in soil. The MDMAL method was more rapid than the simple digestion method or microwave digestion process and could be an alternative approach for the analysis of heavy metals in solid samples [158]. Aaron et al reported an efficient chemical strategy for the crosslinking of polymer chains based on the $\mathrm{N}$ - and $\mathrm{C}$ - of proteins $(\mathrm{CPC} \rightarrow \mathrm{N} / \mathrm{C}-\mathrm{P})$, producing hybrid hydrogels which was related to biomolecules. This compound is largely independent of the protein's sequence; it can in principle be used to incorporate of polypeptide into a polymer based on uniform linkages. They used cysteine for this strategy to convert metallothioneins into a recyclable polymer gel that can remove heavy metals from water samples [159]. Shirkhanloo et al reported a novel method based on amine-functionalized mesoporous silica UVM-7 as nanoadsorbent for manganese (II) and manganese (VII) extraction in waters by ultrasound assisted-dispersive-micro-solid phase extraction (US-D- $\mu$-SPE) procedure. They were used NH2-UVM7 for speciation of Mn(II) and $\mathrm{Mn}(\mathrm{VII})$ ions at $\mathrm{pH}$ of 8 and 5 , respectively which was determined by(AT-F AAS. The validation of the method was also performed by the standard reference material [160]. Also, Shirkhanloo et al introduced a carboxyl-functionalized nanoporous graphene (NG-COOH) as solid phase sorbent for speciation of trace $\mathrm{Hg}$ (II) and $\mathrm{R}-\mathrm{Hg}\left(\mathrm{CH}_{3} \mathrm{Hg}^{+}\right.$and $\left.\mathrm{C}_{2} \mathrm{H}_{5} \mathrm{Hg}^{+}\right)$in waters by US-D-IL- $\mu$-SPE $(\mathrm{pH}=8)$. Ionic liquid was used for trapping of sorbent from water sample. After back extraction, $\mathrm{Hg}$ (II) concentration determined with flow injectioncold vapor-atomic absorption spectrometry (FICV-AAS) [161]. Also they were reported a new method based on ultrasound assisted-dispersive solid-liquid multiple phase microextraction (USADSLMPME) for speciation of trace amounts of inorganic arsenic (III and V) and total organic arsenic (TOA) in waters and human urine samples. By procedure NH2-UVM7 were immersed in ionic liquid (IL) as an extraction phase. Then, the mixture of NH2-UVM7 and IL/acetone [HMIM] [PF6]/AC) was injected to sample at $\mathrm{pH}$ of 3.5.
After ultrasonic, $\mathrm{As}(\mathrm{V})$ anion extracted by binding to amine group. Total amount of inorganic arsenic (TIA) was determined after oxidization of As(III) to As(V) by ETAAS and As(III) was calculated by the subtracting TIA and As(V) content [162].

\section{Results and Conclusions}

Kaipei Qiu was introduced a novel adsorption process for heavy metals from waters. In the adsorption process, the desorption and repeatability are significant parameters for developing new adsorbents for practical applications. The heavy metals such as, $\mathrm{Pb}^{2+}, \mathrm{Cd}^{2+}, \mathrm{Cu}^{2+}$, and $\mathrm{Ni}^{2+}$ were adsorbed by UFMNPs which was shown in Scheme 2. The adsorption kinetics is one of the important characteristics defining the effectiveness of an adsorbent, which describes the solute uptake rate by controlling the diffusion process and the residence time of an adsorbate uptake at the solid/solution interface. The results in this quaternary $\mathrm{Pb}-\mathrm{Cd}-$ $\mathrm{Cu}-\mathrm{Ni}$ system indicated that the rate constant of $\mathrm{Pb}^{2+}\left(0.045 \mathrm{~g} \mathrm{mg}^{-1} \mathrm{~min}^{-1}\right)$ was higher than the rate constants of $\mathrm{Cu}^{2+}\left(0.008 \mathrm{~g} \mathrm{mg}^{-1} \mathrm{~min}^{-1}\right), \mathrm{Cd}^{2+}(0.005$ $\left.\mathrm{g} \mathrm{mg}^{-1} \mathrm{~min}^{-1}\right)$, and $\mathrm{Ni}^{2+}\left(0.003 \mathrm{~g} \mathrm{mg}^{-1} \mathrm{~min}^{-1}\right)$, further demonstrating the strong affinity of $\mathrm{Fe}_{3} \mathrm{O}_{4} \mathrm{NPs}$ for $\mathrm{Pb}^{2+}[139]$.

Soylak and Tuzen studied on the amounts of $\mathrm{Cr}, \mathrm{Cu}, \mathrm{Ni}, \mathrm{Zn}, \mathrm{Mn}, \mathrm{Fe}, \mathrm{Co}$, and $\mathrm{Al}$ in drinking water samples based on novel extraction technique using atomic absorption spectrometry in Turkey. According to their studies, the concentration of $\mathrm{Cr}$ in natural water was often very small. Based on results, the hexavalent form of chromium $\left(\mathrm{Cr}_{\mathrm{VI}}\right)$ is ranged between 3.14 and $6.08 \mu \mathrm{gL}^{-1}$. The mean of $\mathrm{Cr}$ levels in the waters of the area of Turkey was equal to4.40 $\mu \mathrm{gL}^{-1}$. Maximum tolerable limit of concentration of total chromium in drinking water was less than $50 \mu \mathrm{g} \mathrm{L}^{-1}$ (Tlv of chromium by WHO $>50 \mu \mathrm{g} \mathrm{L}^{-1}$ ) [101]. The permissible value of $\mathrm{Ni}$ in drinking water was less than $20 \mu \mathrm{g} \mathrm{L}^{-1}$. The mean level of $\mathrm{Ni}$ in the water samples, in the area of Tokat, Turkey was equal to $3.82 \mu \mathrm{g} \mathrm{L}^{-1}$ which was lower than standard references such as EPA, WHO. Also, according to their study, the drinking water sample from Turhal was the highest nickel value 


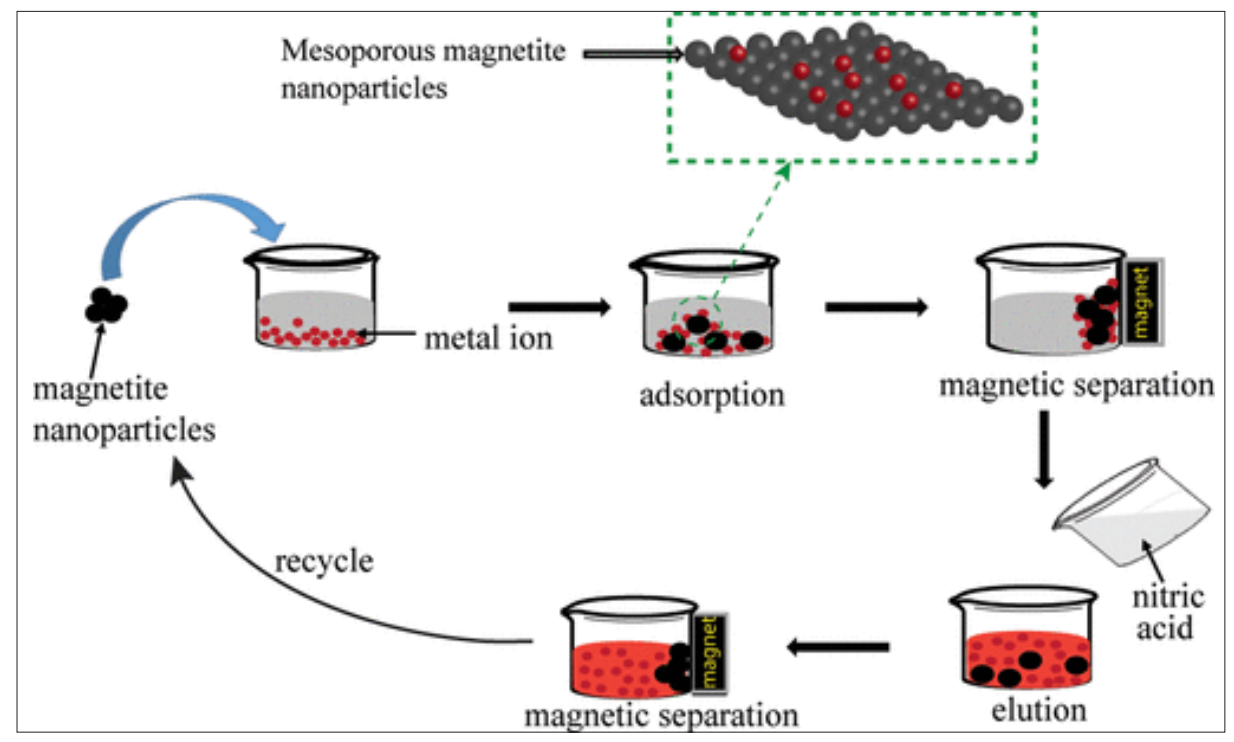

Scheme 2. Removal of heavy metal Ions by desorption process [139]

$\left(5.35 \pm 0.28 \mu \mathrm{g} \mathrm{L}^{-1}\right)$ and the city center of Tokat was the lowest $\left(2.16 \pm 0.19 \mu \mathrm{gL}^{-1}\right)$ [101]. They showed, the amount of $\mathrm{Cu}$ was in the range of 4.44-7.43 $\mu \mathrm{gL}^{-1}$. In Erbaa, Turkey, Cu was substantially lower than the permissible limit defined by WHO (1.0 $\left.\mu \mathrm{gL}^{-1}\right)$ in drinking waters [101]. In addition, mean level of concentration of $\mathrm{Cu}$ was equal to $6.01 \mu \mathrm{g}$ $\mathrm{L}^{-1}$. Therefore, no contamination of $\mathrm{Cu}$ was there in the drinking water samples. The guideline value for zinc in drinking-water is given as $5.0 \mathrm{mg} / \mathrm{l}$ by WHO. The concentration of Zinc ranged from 4.16 to $8.44 \mu \mathrm{g} \mathrm{L}^{-1}$ in the drinking water samples. The mean level of zinc was obtained $6.12 \mu \mathrm{g} \mathrm{L}{ }^{-1}$, which was more than the permissible limit value $\left(5.0 \mathrm{mg} / \mathrm{L}^{-1}\right)$ [101]. Many published methods were reported for determination and sample preparation of heavy metals in water and biological samples [Table 1-3]. Chromium speciation based on acetylcysteine (NAC) by dispersive liquidliquid bio-microextraction was achieved in human blood samples by shirkhanloo et al. By method, Ionic liquid (1-hexyl-3-methylimidazolium hexafluorophosphate) was rapidly injected into the blood samples containing $\mathrm{Cr}^{3+}$, which have already complexed by NAC at $\mathrm{pH}$ from 5 to 8 . By optimizing, the linear range, limit of detection and preconcentration factor were achieved 0.03-4.4 $\mu \mathrm{g}$ $\mathrm{L}^{-1}, 0.005 \mu \mathrm{g} \mathrm{L}-1$, and 10 respectively [163,164]. Also, chromium speciation was reported by other researcher [165-172]. Xiaogang Luo et al explained a novel sorbent for absorption heavy metals from waters by syntesis of MCB. The carboxyl decorated magnetite $\left(\mathrm{Fe}_{3} \mathrm{O}_{4}\right)$ nanoparticles (MN$\mathrm{CA}$ ) were obtained by postmodifying the magnetite surface with citric acid. The nanoparticles of $\mathrm{Fe}_{3} \mathrm{O}_{4}$ were added to $0.1 \mathrm{M}$ citric acid under ultrasonic condition for $45 \mathrm{~min}$, and the reaction was kept for $4 \mathrm{~h}$ at room temperature. A magnet was used to separate the $\mathrm{MN}-\mathrm{CA}$, and then the prepared $\mathrm{MN}-$ CA samples were rinsed thoroughly with acetone and double distilled water. The proposed method based on MN-CA followed by Scheme 3 for adsorption heavy metals from waters [145].

Naeemullaha et al showed, the effect of main parameters on extraction of vanadium in waters was evaluated by $\mu$ S-SHS procedures [102]. For optimizing, Statistical assessment of $\mu \mathrm{S}$ SHS method, Screening and optimization of experimental variables and selectivity of the $\mu \mathrm{S}$ SHS method was studied and finally, the method was validated by CRM (SLRS-4 Riverine water samples). The optimization of experimental variables followed with screen out of the volume of SHS, $\mathrm{pH}$, volume of $\mathrm{Na}_{2} \mathrm{CO}_{3}$ and volume of $\mathrm{H}_{2} \mathrm{SO}_{4}$ solution as a extraction efficiency with t-value $(95 \%)$ of 2.365 . The simple, fast and switchable hydrophilicity microextraction (SHM) couple with ETAAS through micropipette tip 


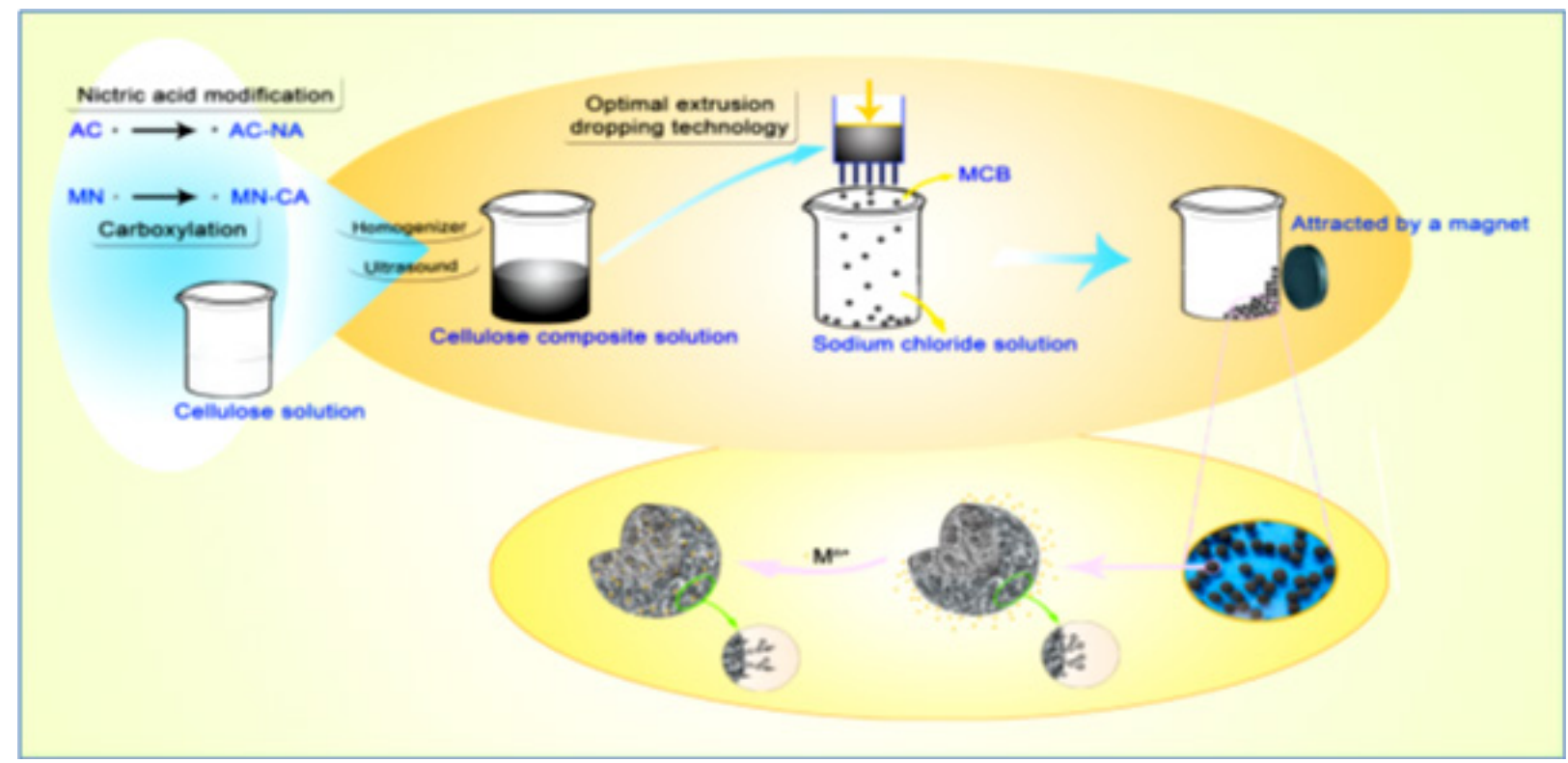

Scheme 3. depiction of preparation of MCB and the adsorption mechanism of heavy metal ions by MCB [145].

syringe system ( $\mu \mathrm{S}-\mathrm{SHS})$ was used for separation and determination of vanadium in food and water samples. The $\mu$ S-SHS method introduced an ideal sample preparation for vanadium extraction. The simple, fast and applied method based on SHM had good efficiency as compared with conventional methods for extraction of vanadium [102]. Also, the proposed method based on $\mu \mathrm{S}-\mathrm{SHS}$ compared with published method and results showed high precision and accuracy results with low LOD and RSD (Table 1). Moreover, the graphical abstract of the $\mu$ S-SHS was shown in Figure 3.

Many separation methods were used for determination of ultra-trace metals in different matrix, such as Liquid-liquid microextraction, dispersive liquid-liquid microextraction, solidphase microextraction, selective dispersive micro solid-phase extraction, traditional organic solvents, and switchable solvent, ultrasound assisted-dispersive-ionic liquid-micro-solid phase extraction and ultrasound assisted-dispersive solid-liquid multiple phase microextrbased on action [Table 1-3]. Kaiser, Zheng and Feng used a novel two-dimensional polymers crystals (TDPC) synthesis with nano size in waters through reaction between amine and anhydride monomers by surfactant monolayers. They showed high crystallinity polymers $(\mathrm{CsP})$ with thickness $(2-3$ $\mathrm{nm})$ and an crystal size $\left(3.5 \mu \mathrm{m}^{2}\right)$. The molecular structure of the materials, were characterized using $\mathrm{X}$-ray scattering and TEM. The structure and TEM was shown in Figure 4. The formation of CsP is attributed to the pre-organization of monomers at interface phase (water- surfactant). Finally, micrometre-sized and few layer TDPC were grown. This material was used in different application such as removal heavy metals [156].

Rosillo-Lopez et al used carboxylated graphene nanoflakes (CX-GNF) and nanographene oxide (GO) for extracting of heavy metals such as, $\mathrm{Fe}^{2+}$, $\mathrm{Cu}^{2+}, \mathrm{Fe}^{3+}, \mathrm{Cd}^{2+}$ and $\mathrm{Pb}^{2+}$ in waters. The carboxylic acid groups (cx-GNF) have strong binding with heavy metal cations. CX-GNF with additional chemicalfunctionalization procedures can easily compete

Table 1. The proposed method based on $\mu$ S-SHS compared with published method [102]

\begin{tabular}{lllllll}
\hline Sample prepration & Technique & SV & RSD $\%$ & LOD $\left(\boldsymbol{\mu g} . \mathbf{L}^{-1}\right)$ & EF/PF & References \\
\hline SPE & ICP-OES & 10 & 3.4 & 0.06 & 45 & 68 \\
CPE approach & Spectrometric & $\ldots$ & $\ldots$. & 1.4 & $\ldots$. & 70 \\
CPE & ETAAS & 50 & $\ldots$. & 0.042 & 125 & 71 \\
$\mu$ S-SHS & ETASS & 10 & 2.2 & 0.0075 & 120 & 76 \\
\hline
\end{tabular}




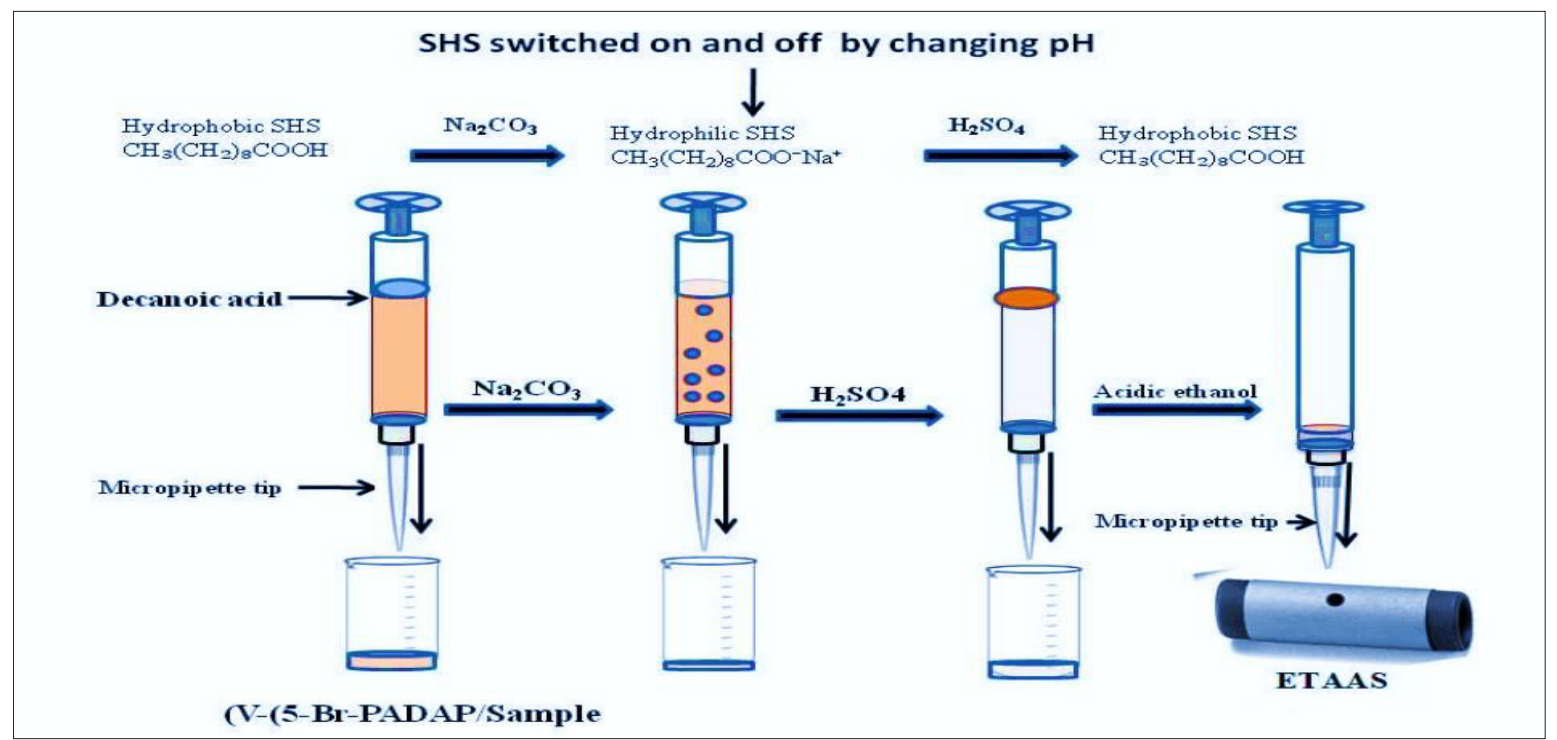

Fig. 3. The graphical abstract of the $\mu$ S-SHS [102].

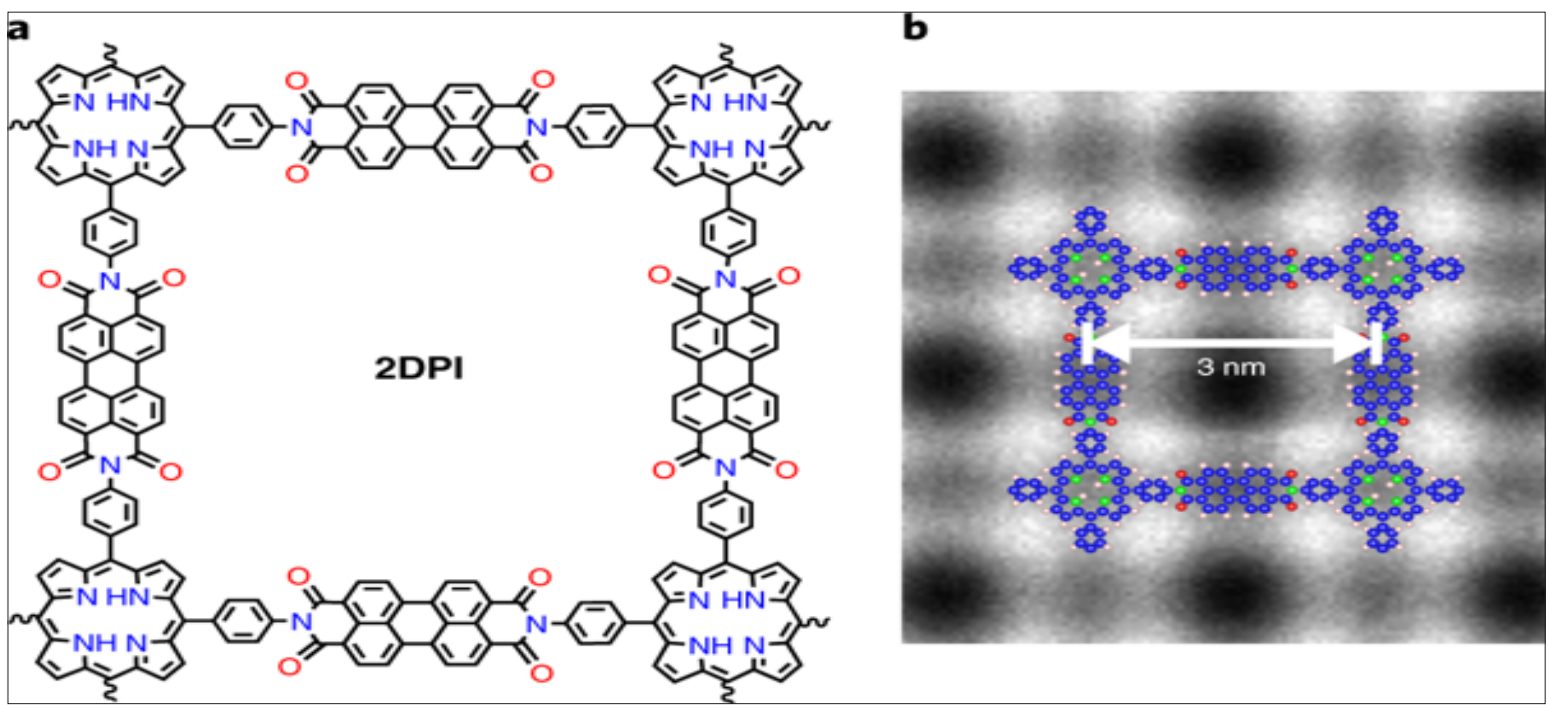

Fig. 4. The structurea and b) TEM of two-dimensional polymers crystals (TDPC)[156]

with other carbon materials such as $\mathrm{G}$ and GO for heavy-metal extraction (Fig. 5). Furthermore, the cx-GNF material extracted $\mathrm{Pb}^{2+}$ ions in the presence of excess $\mathrm{Ca}^{2+}$ or $\mathrm{Mg}^{2+}$ cations which were already existed in environmental matrix. So, the CX-GNF material showed the highest potential for extraction of heavy-metal from water as compared to other graphene materials [157]. Zhao et al used multithroughput dynamic microwave-assisted leaching (MDMAL) for determination of $\mathrm{Cu}, \mathrm{Mn}, \mathrm{Zn}$ and $\mathrm{Pb}$ in soil. This method combines the microwave and dynamic leaching technique for five samples within 15 min (Fig. 6). $\mathrm{HNO}_{3}$ aqueous solution was

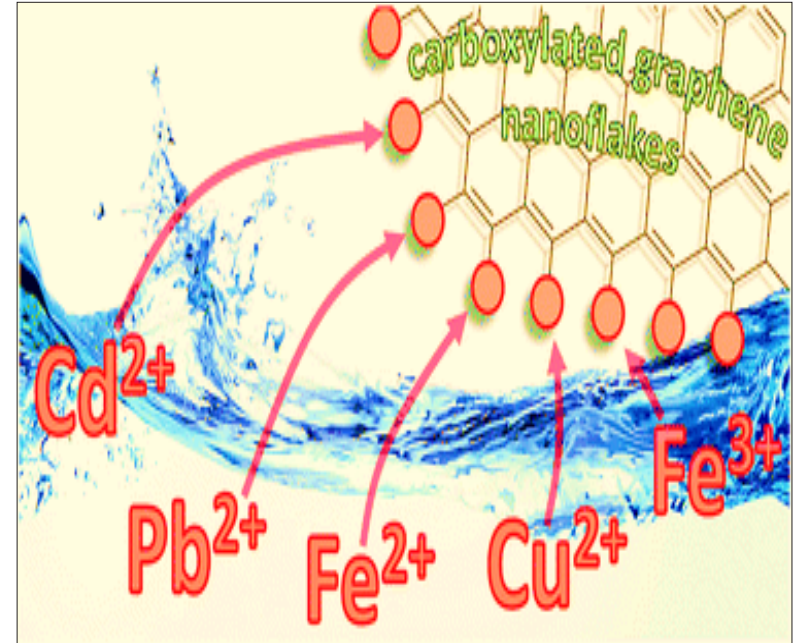

Fig. 5. Heavy metal extraction by cx-GNF. 


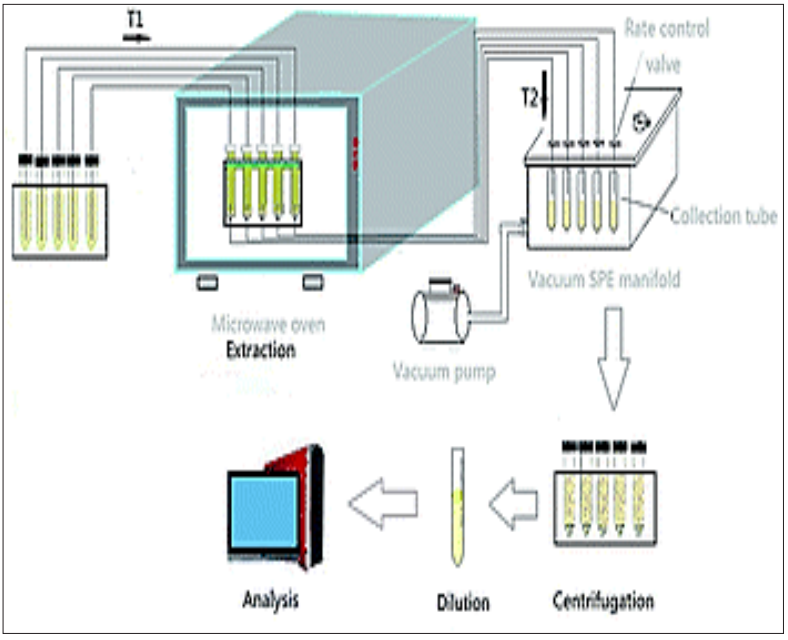

Fig. 6. Heavy metal extraction by MDMAL

employed as leachant at a flow rate of $1.5 \mathrm{~mL} \mathrm{~min}^{-1}$. The leaching condition were above $95 \%$ for $\mathrm{Cu}, \mathrm{Mn}$, $\mathrm{Zn}, \mathrm{Pb}$ and lower for $\mathrm{Cr}, \mathrm{Cd}, \mathrm{Ni}$ and $\mathrm{Co}$, compared to the conventional method. The mean of RSD of intraand inter-day of $\mathrm{Cu}, \mathrm{Mn}, \mathrm{Zn}$, and $\mathrm{Pb}$ were $4 \%$ and $6 \%$, respectively. The proposed method was more rapid than the conventional digestion method and could be an alternative approach for the analysis of heavy metals in complex solid samples [158].

Aaron et al, showed that, the crosslinking of polymer chains based on the $\mathrm{N}$ - and $\mathrm{C}$ - of proteins $(\mathrm{CPC} \rightarrow \mathrm{N} / \mathrm{C}-\mathrm{P})$ was used as a key of the proteins which was captured trace amounts of heavy metals such as cadmium in the presence of innocuous ions in contaminated water sample. Protein-cross-linked hydrogels introduced for sequestration of heavy metal ions in water samples. As Figure 7, the Pea metallothioneins (PMTs) can capture toxic metal ions by condensing to form binding pockets. The synthetic route to access these materials involves the introduction of ketones on both protein termini. These groups are then used to cross-link alkoxyamine-substituted polymers through oxime formation [159]. Shirkhanloo et al used $\mathrm{NH}_{2}-\mathrm{UVM}_{7}$ based on US-D- $\mu$-SPE method for speciation of manganese in water samples. The batch adsorption

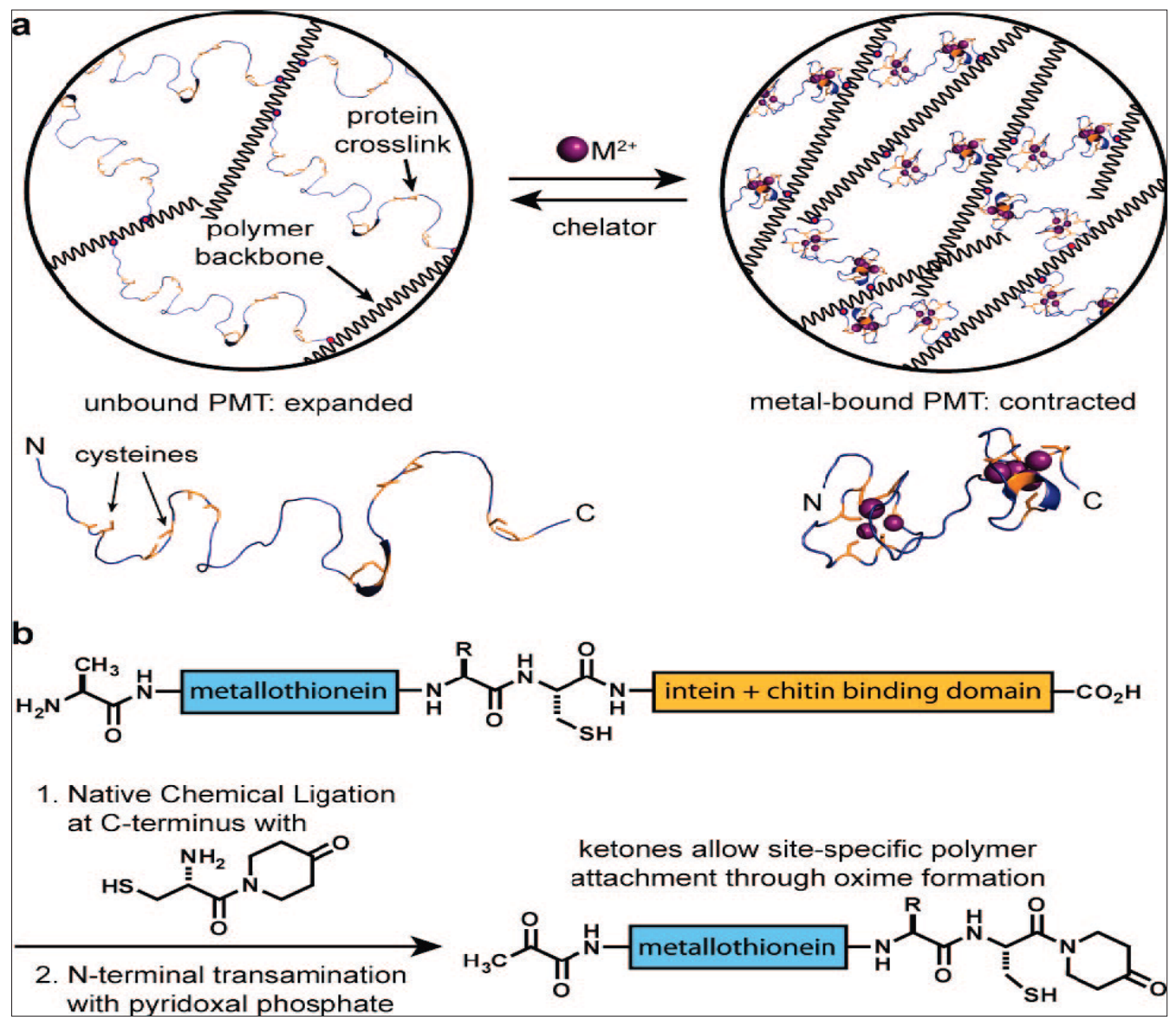

Fig. 7. Pea metallothioneins (PMTs) can capture toxic metal ions a) Condensing to form binding pockets b) Ketones used to cross-link alkoxyamine-substituted polymers [159] 
capacity of $\mathrm{NH}_{2}-\mathrm{UVM}_{7}$ for $\mathrm{Mn}(\mathrm{II})$ and $\mathrm{Mn}(\mathrm{VII})$ ions was found to be $1733 \mu \mathrm{mol} \mathrm{g}{ }^{-1}$ and $570 \mu \mathrm{mol}$ $\mathrm{g}^{-1}$, respectively. In optimized parameters, LOD $(3 \mathrm{Sb} / \mathrm{m})$, and LOQ $(10 \mathrm{Sb} / \mathrm{m})$ were $0.007 \mu \mathrm{g} \mathrm{L}^{-1}$ and $0.03 \mu \mathrm{g} \mathrm{L}^{-1}$ for $\mathrm{Mn}(\mathrm{II})$. The mean preconcentration factors for $\mathrm{Mn}$ (II) and $\mathrm{Mn}$ (VII) were calculated as 102.3 and 98.8 with RSD about $2.8 \%$, respectively (Fig. 8). The regression equations for the calibration curves of $\mathrm{Mn}(\mathrm{II})$ and $\mathrm{Mn}(\mathrm{VII})$ were $\mathrm{A}=9.8438$ $\mathrm{C}+0.0053$ ( $\mathrm{R} 2=0.9997)$, and $\mathrm{A}=9.6922 \mathrm{C}+0.0045$ $(\mathrm{R} 2=0.9995)$, respectively [160]. In addition, Shirkhanloo et al used NG-COOH for speciation of trace mercury in waters by US-D-IL- $\mu$-SPE. Under optimized conditions, the linear range, LOD and PF/EF were obtained 0.03-6.3 $\mu \mathrm{g} \mathrm{L}^{-1}, 0.0098 \mu \mathrm{g}$ $\mathrm{L}^{-1}$ and 10.4 for caprine blood samples, respectively. The developed method was successfully applied to natural water and human/caprine blood samples. In order to validate the method described, two certified standard reference materials, NIST-SRM $995 \mathrm{c}$ (mercury species in caprine blood) and NISTSRM1641e (total mercury inwater), were analyzed by US-D-IL- $\mu$-SPE [161]. They used NH2-UVM7 based on USA-DSLMPME for speciation of trace amounts arsenic (III and V) in waters and human

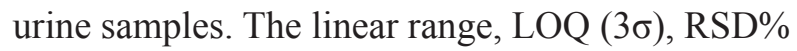
and $\mathrm{EF}$ for $\mathrm{As}(\mathrm{V})$ were obtained $0.02-1.65 \mu \mathrm{g}$

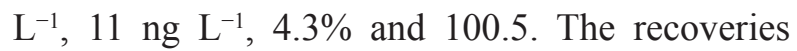
$(95-102 \%)$ was achieved by certified reference material in urine (NIST-SRM). The mean of LOD was obtained $3.3 \mathrm{ng} \mathrm{L}^{-1}$ and $2.7 \mathrm{ng} \mathrm{L}^{-1}$ for human urine and standard samples, respectively (intra-day, Mean of LOD = 3)[162].

\subsection{Chemistry techniques for heavy metals}

Also, many chemistry techniques were reported in published papers for separation, extraction, preconcentration and speciation metals in different matrixes (Table 2). Recently, the liquid-liquid extraction methods (LLE) were used for separation and determination heavy metals from water and human biological samples. Some of LLE techniques such as, ultrasonic-thermostatic-assisted cloud point extraction procedure (UTA-CPE-FAAS), aqueous solvent-based dispersive liquid-liquid microextraction (AS-DLLME), cloud point extraction - slotted quartz tube-flame atomic absorption spectrometry (CPE-SQT-FAAS), surfactant-assisted dispersive liquid-liquid micro-extraction (SA-DLLME-FAAS), switchable liquid-liquid microextraction (SLLMESQT-FAAS), surfactant-Based Dispersive Liquid-Liquid Microextraction based on FAAS(SBDLLME-FAAS), vortex-assisted DLLME based on voltammetric (VA-DLLME-VM), microwaveassisted extraction - inductively coupled plasmaoptical emission spectrometry (MAE-ICP-OES), Ionic liquid-based microwave-assisted dispersive liquid-liquid microextraction (IL-based MADLLME), Ionic liquid-based dispersive liquidliquid microextraction (IL-DLLME), Ionic liquid

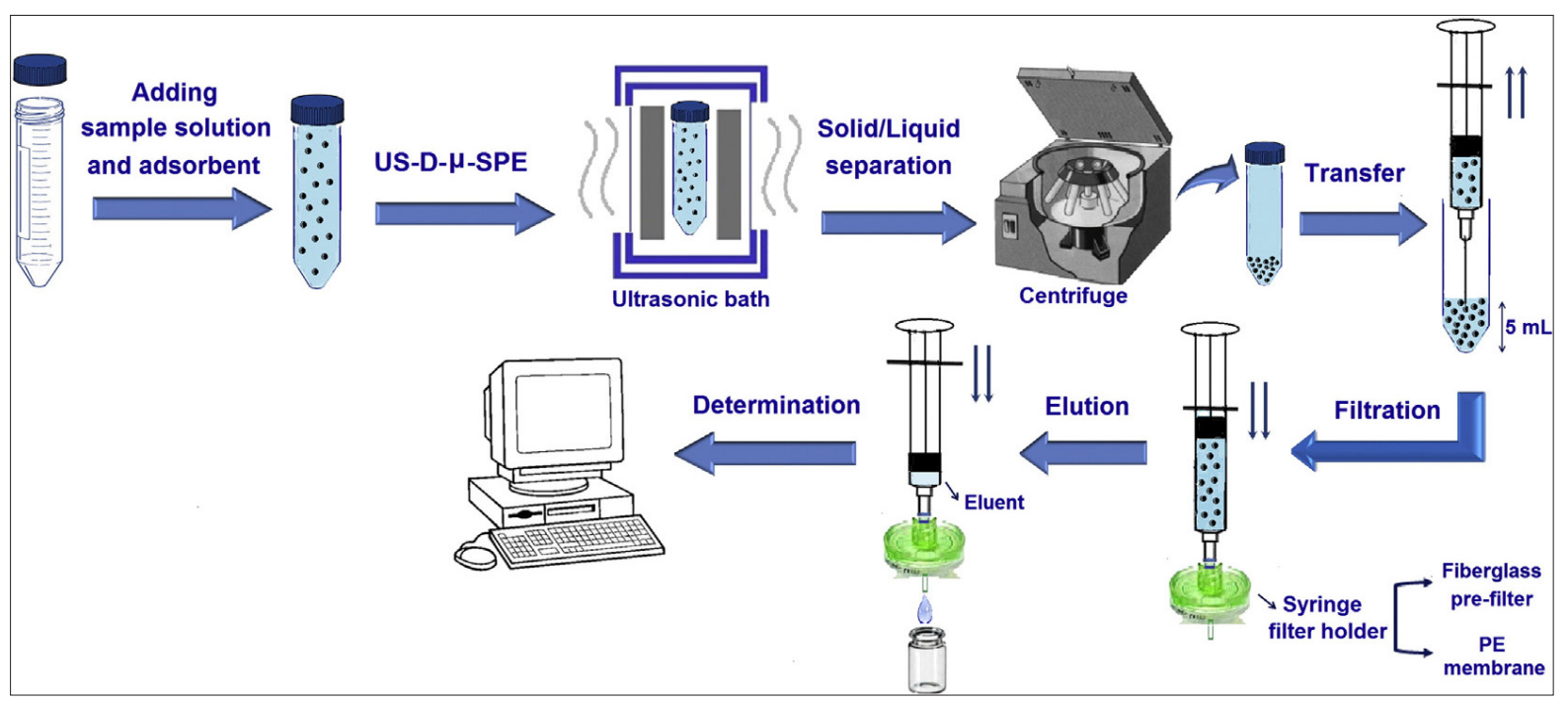

Fig. 8. Procedure of Mn speciation based on $\mathrm{NH}_{2}-\mathrm{UVM}_{7}$ by US-D- $\mu-S P E$ procedure [160]. 
Table 2. Solvent extraction for determination and separation of heavy metals in different matrix [173-197]

\begin{tabular}{|c|c|c|c|c|c|c|}
\hline Sample & Metals & Method & Solvent/Ragent & EF/PF & LOD $\mu \mathrm{g} \mathrm{L}^{-1}$ & Ref. \\
\hline Wastewater & $\mathrm{Cd}$ & DLLME/SQT-FAAS & DPC & 93.3 & 0.5 & [173] \\
\hline $\begin{array}{l}\text { Milk } \\
\text { Vegetables }\end{array}$ & $\mathrm{V}(\mathrm{V})$ and $\mathrm{Mo}(\mathrm{VI})$ & UTA-CPE-FAAS & $\begin{array}{l}\text { Nile blue A - } \\
\text { PONPE }\end{array}$ & 145 and 115 & 0.86 and 1.55 & [174] \\
\hline \multicolumn{7}{|l|}{ Foodstuffs } \\
\hline Parsley & $\mathrm{Cd}$ & CPE-SQT-FAAS & DPC & 60 & 0.0007 & [175] \\
\hline Tap & $\mathrm{Zn}$ & SA-DLLME-FAAS & PAR & ----- & 0.5 & [176] \\
\hline \multicolumn{7}{|l|}{ River } \\
\hline \multicolumn{7}{|l|}{ Well water } \\
\hline Wastewater & $\mathrm{Co}$ & DLLME/SQT-FAAS & DPC & 86.56 & 0.97 & [177] \\
\hline $\begin{array}{l}\text { Tea } \\
\text { vitamin B12 }\end{array}$ & Co & SLLME-SQT-FAAS & Schiff base ligand & 107.7 & 3.1 & [178] \\
\hline Food & $\mathrm{Cu}(\mathrm{II})$ & SB-DLLME-FAAS & Triton X-114 & 50 & 1.61 & [179] \\
\hline \multicolumn{7}{|l|}{ Water Samples } \\
\hline Milk & $\mathrm{Cd}(\mathrm{II}), \mathrm{Cu}(\mathrm{II}), \mathrm{Pb}(\mathrm{II})$ & DLLME/FAAS & TDES & ---- & $0.38-0.42$ & [180] \\
\hline Chocolate & $\mathrm{Ni}$ & PV-IS-DLLME & APDC & 17 & 100.0 & [181] \\
\hline Urine & $\mathrm{Hg}$ & VA-DLLME-VM & AuNPS-PE & --- & $1.1-1.3$ & [182] \\
\hline human blood & $\mathrm{Cr}(\mathrm{III}$ and $\mathrm{VI})$ & CP-DILLME-ET-AAS & IICDET & 25.2 & 0.0054 & [183] \\
\hline Human serum & $\mathrm{Cd}$ & DLLME-ETAAS & TSILs & 10.2 & 0.005 & [184] \\
\hline Human blood & $\mathrm{Cr}(\mathrm{III}$ and $\mathrm{VI})$ & IL-DLLBME-ETAAS & NAC & 10 & 0.005 & [185] \\
\hline Biodiesel & $\mathrm{Na}, \mathrm{K}, \mathrm{Ca}$ and $\mathrm{Mg}$ & RP-DLLME/FAAS & Iisopropanol, $\mathrm{HNO}_{3}$, & --- & $0.006-0.026$ & ]186] \\
\hline Water & $\mathrm{Ta}(\mathrm{I}), \mathrm{Ta}$ (III) & IL DLLME-ET-AAS & [C6MIm][PF6] & 100 & $3.3 \mathrm{ng} \mathrm{L}^{-1}$ & [187] \\
\hline Cosmetic & $\mathrm{Hg}(\mathrm{II}), \mathrm{MeHg}+, \mathrm{EtHg}+$ & HPLC-ICPMS & [C6MIm][PF6] & $760,115,235$ & $1.3 \mathrm{ng} \mathrm{L}^{-1}$ & [188] \\
\hline Wines & As (III) & DLLME-ETAAS & [C8MIm][PF6] & ---- & $5.0 \mathrm{ng} \mathrm{L}^{-1}$ & [189] \\
\hline Water & $\mathrm{Cu}(\mathrm{II})$ & DLLME-FAAS & $\begin{array}{c}{[\mathrm{C} 4 \mathrm{MIm}][\mathrm{PF} 6] \text { or }} \\
{[\mathrm{C} 16 \mathrm{C} 4 \mathrm{Im}][\mathrm{Br}]}\end{array}$ & 54 & $3300 \mathrm{ng} \mathrm{L}^{-1}$ & [190] \\
\hline $\begin{array}{l}\text { Water and } \\
\text { leaves }\end{array}$ & $\mathrm{Rh}(\mathrm{III})$ & US-IL DLLME-FAAS & {$[\mathrm{C} 8 \mathrm{MIm}][\mathrm{NTf} 2]$} & ---- & 0.37 & [191] \\
\hline Water & $\mathrm{V}(\mathrm{IV})$ and $\mathrm{V}(\mathrm{V})$ & TC-IL DLLME-ETAAS & [C4MIm][PF6] & ---- & 0.0049 & [192] \\
\hline $\begin{array}{l}\text { Tea, Soda } \\
\text { Beer }\end{array}$ & $\mathrm{Se}(\mathrm{IV})$ & $\begin{array}{l}\text { USA-IL-DLLME- } \\
\text { ETAAS }\end{array}$ & [C6MIm][NTf2] & 150 & 12 & [193] \\
\hline \multicolumn{7}{|l|}{ Milk } \\
\hline Water & $\mathrm{Au}, \mathrm{Ag}$ & $\begin{array}{c}\text { MRTILs- DLLME- } \\
\text { ETAAS }\end{array}$ & {$\left[\mathrm{C}_{5}(\mathrm{MIM})_{2}\right]\left[\mathrm{NTf}_{2}\right]_{2}$} & 245 and 240 & 3.2 and 3.7 & [194] \\
\hline Food & $\begin{array}{l}\mathrm{Zn}, \mathrm{P}, \mathrm{Cd}, \mathrm{Pb}, \mathrm{Fe}, \mathrm{Mn} \\
\mathrm{Mg}, \mathrm{Cu}, \mathrm{Ca}, \mathrm{Al}, \mathrm{Na}, \mathrm{K}\end{array}$ & MAE -ICP-OES & MAE & ---- & $\begin{array}{l}0.01 \mathrm{mg} \mathrm{kg}^{-1} \\
-7.8 \mathrm{mg} \mathrm{kg}^{-1}\end{array}$ & [195] \\
\hline Water & $\mathrm{Pd}$ and $\mathrm{Pt}$ & CPE-ICP OES & MBT & --- & 0.525 and 0.752 & [196] \\
\hline Water serum & $\mathrm{Cu}(\mathrm{II})$ & $\begin{array}{c}\text { IL-mE-DLLME-CPE- } \\
\text { ETAAS }\end{array}$ & Oxine-IL & 70 & 0.132 & [197] \\
\hline
\end{tabular}

EF: Enrichment Factor

UTA-CPE-FAAS: ultrasonic-thermostatic-assisted cloud point extraction procedure AS-DLLME: Aqueous solvent-based dispersive liquid-liquid microextraction DPC: Diphenylcarbazone

Nile blue A: 9-(diethylamino)benzo[a]phenoxazin-5-ylidene]azanium; sulfate-PONPE (polyoxyethylene-nonylphenyl ether

ETAAS: Electrothermal atomic absorption spectrometry

FAAS: Flame atomic absorption spectrometry

SQT-FAAS: Slotted quartz tube-flame atomic absorption spectrometry

CPE-SQT-FAAS: Cloud point extraction - slotted quartz tube-flame atomic absorption spectrometry

DPC: Diphenylcarbazone

SA-DLLME-FAAS : Surfactant-assisted dispersive liquid-liquid micro-extraction

PAR: 4-(2-pyridylazo) resorcinol

SLLME-SQT-FAAS: Switchable liquid-liquid microextraction
SB-DLLME-FAAS: Surfactant-Based Dispersive Liquid-Liquid Microextraction/FAAS Triton X-114: Surfactant

TDES: Ternary deep eutectic solvent

APDC: ammonium pyrrolidine dithiocarbamate

VA-DLLME-VM: Vortex-assisted DLLME/voltammetric

AUNPS-PE: gold nanoparticle-modified screen-printed electrodes

MAE-ICP-OES: microwave-assisted extraction-inductively coupled plasma-optical emission spectrometry

MBT: 2-mercaptobenzothiazole

Oxime-IL: 8-hydroxyquinoline-IL

UA-DLLME: Ultrasound-assisted dispersive liquid-liquid microextraction

UAE- IL-DLLME: Ultrasonic-assisted ionic liquid based dispersive liquid-liquid microextraction

USA-DLLME: Ultrasound-assisted dispersive liquid-liquid microextraction

USA-IL-DLLME: Ultrasound assisted ionic liquid dispersive liquid-liquid microextraction 
ultrasound assisted dispersive liquid-liquid microextraction (IL-UA-DLLME), In-situ ionic liquid dispersive liquid-liquid microextraction(in-situ IL-DLLME), microwave-assisted extraction and dispersive liquid-liquid microextraction (MAEDLLME), magnetic ionic liquid-based dispersive liquid-liquid microextraction) MIL-based DLLME), magnetic stirring-assisted dispersive liq- uid-liquid microextraction (MSA-DLLME), magnetic stirrer induced dispersive ionic-liquid microextraction (MS-IL-DLLME), microwave-assisted dispersive liquid-liquid microextraction(MWADLLME), ionic liquid dispersive microextraction (IL-DLLME), surfactant assisted dispersive liquidliquid microextraction (SA-DLLME), switchable solvent-based dispersive liquid-liquid microex-

Table 3. Different sorbents for extraction of heavy metals in human and environmental samples [198- 218]

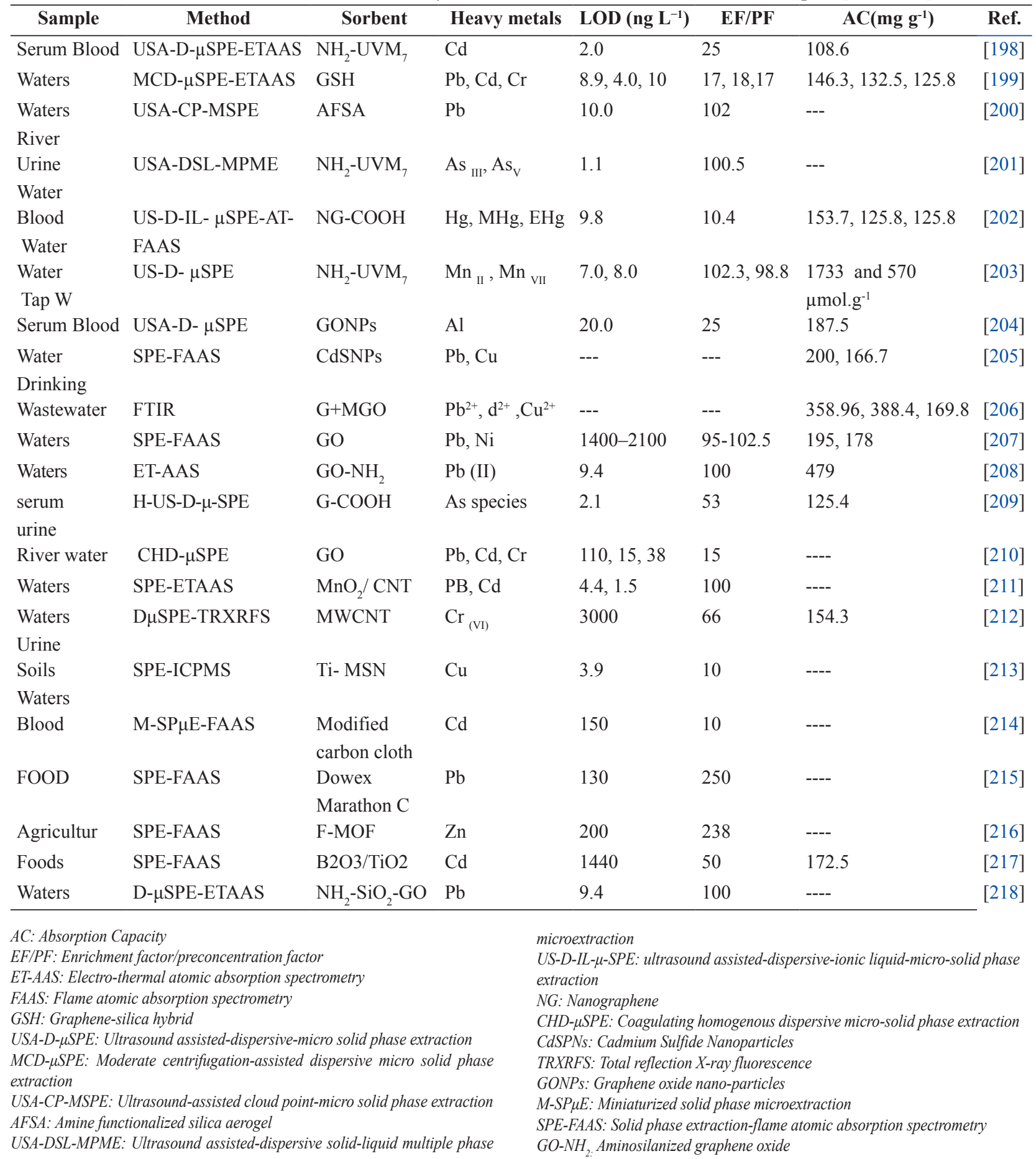


traction (S-DLLME), temperature-assisted ionic liquid-based dispersive liquid-liquid Microextraction (TA-IL-DLLME), ultrasound-assisted dispersive liquid-liquid microextraction (UA-DLLME), ultrasonic-assisted ionic liquid based dispersive liquid-liquid microextraction (UAE- IL-DLLME), ultrasound-assisted dispersive liquid-liquid microextraction (USA-DLLME), ultrasound assisted ionic liquid dispersive liquid-liquid microextraction (USA-IL-DLLME) was used for heavy metal extraction in different matrixes (Table 2) [173-197]. Many researchers were reported other nanomaterial or sorbents for extraction metals and heavy metals from water, wastewaters, air pollution and human biological matrix which were shown in Table 3.

\subsection{Nano particles for extraction heavy metals}

The affinity of $\mathrm{Hg}$ towards $\mathrm{Au}$ was generally achieved by $\mathrm{AuHg}, \mathrm{AuHg} 3$, and $\mathrm{Au3Hg}$ [219]. Lisha et al. reported the removal of $\mathrm{Hg}$ (II) with nanoparticles of $\mathrm{Au}$ (AuNPs) coated on aluminum [220]. NaBH4 helped to reduce $\mathrm{Hg}$ (II) to $\mathrm{Hg}(0)$ and removed by AuNPs with capacity of $4.0 \mathrm{~g} \mathrm{~g}^{-1}$. Also, Jiménez et al. was used citrate-coated AuNPs for extraction mercury in water [221]. Absorption mercury with AuNPs was shown in Figure 9.

Magnetite $\left(\mathrm{Fe}_{3} \mathrm{O}_{4}\right)$ as nanoadsorbent was used for heavy metal removal as environmental friendliness. $\mathrm{Fe}_{3} \mathrm{O}_{4}$ could be easily separated from liquid phase. $\mathrm{Fe}_{3} \mathrm{O}_{4}$ was used for heavy metals treatment in waters [222-224]. Giraldo et al. synthesized magnetite nanoparticles by using a coprecipitation method and were used for extracting of $\mathrm{Pb}$ (II) and $\mathrm{Mn}$ (II) in different samples [225]. In Figure 10, the removal of chromium was shown by chitosan-magnetite nanocomposite.

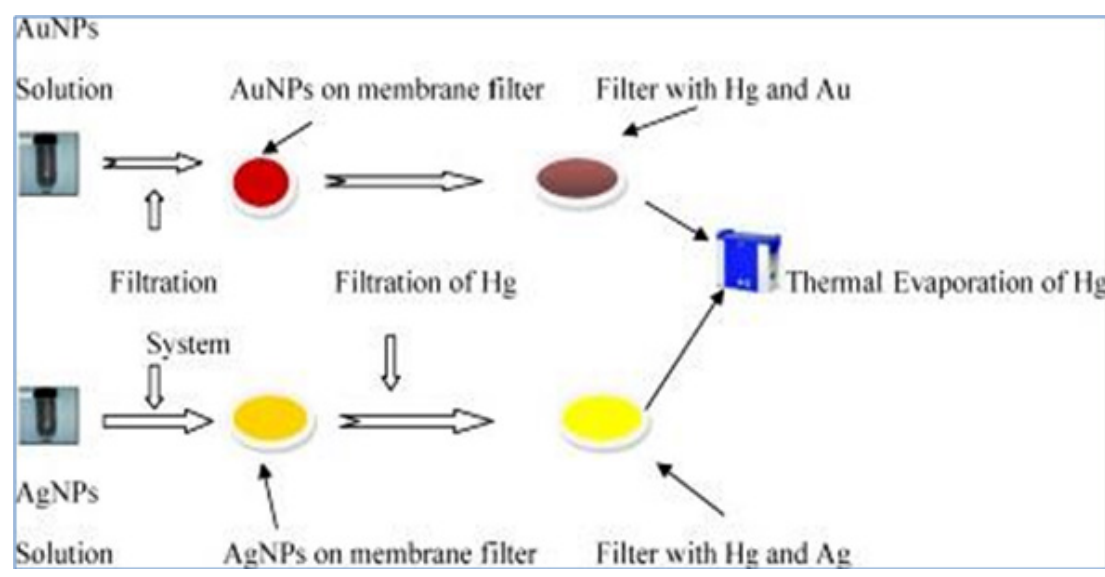

Fig. 9. The absorption mercury by AuNPs

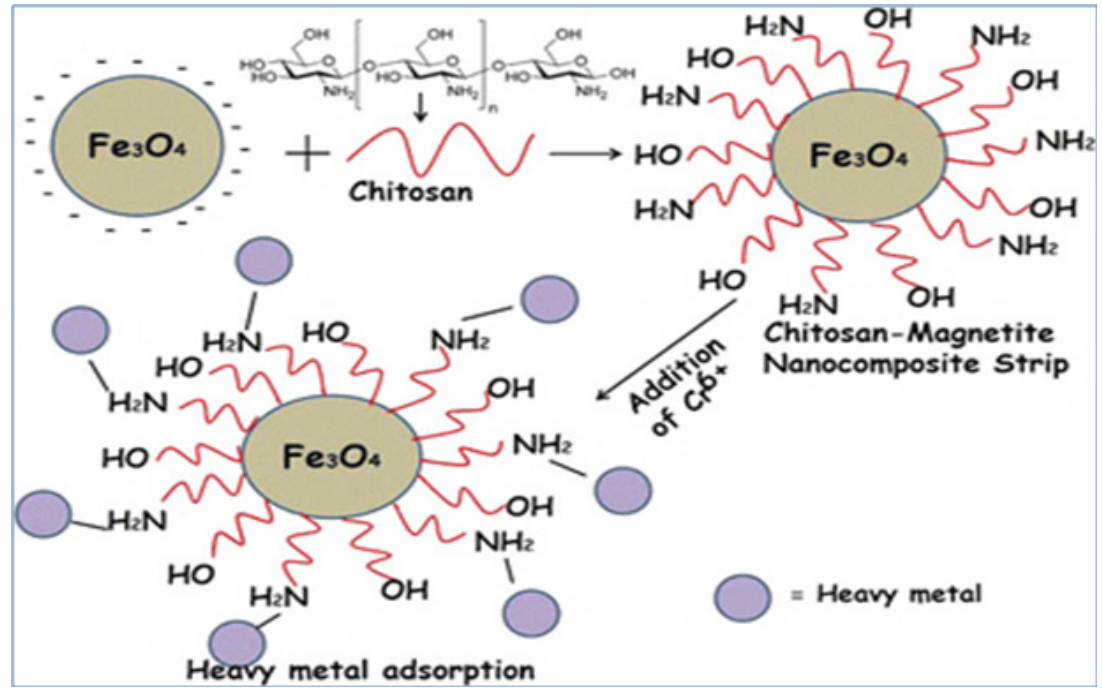

Fig. 10. The removal of chromium by chitosan-magnetite nanocomposite strip 
Magnetite particles are modified with groups such as, MPs-NH2 [226], MPs-COOH [227], MPs$\mathrm{SH}$ [228]. The core-shell structure of PI-b-PEG diblock copolymer encapsulated with iron oxide nanoparticles [229]. PI-b-PEG diblock copolymer was used for removal heavy metals from waters [230]. The nanostructures of amphiphilic diblock copolymers due to the inherent curvature of the polymer were shown in Figure 11 which was used for extraction lead and other heavy metals from different matrixes.

Zero valent iron as nanoparticles of is a $\mathrm{Fe}(0)$ and ferric oxide coating (nZVI) which was used for extraction heavy metals from different matrix
(Figure 3) [231]. Also, nZVI as a novel adsorbent can be removed heavy metals (Fig. 12), such as mercury, chromium, copper, nickel, and cadmium from waters. [232-235]

The silica nanoparticles based on ligand of $\beta$-ketoenol-pyridine-furan (as a selective adsorbent was used for metal removal from waters $(\mathrm{Pb}, \mathrm{Cd}, \mathrm{Zn}, \mathrm{Cu})$ (Scheme 4). The engineered sorbent had high adsorption capacity for capturing toxic heavy metal in environmental samples [236-239].

\section{Conclusions}

In this review paper, constructive issues from novel published papers were selected for studying

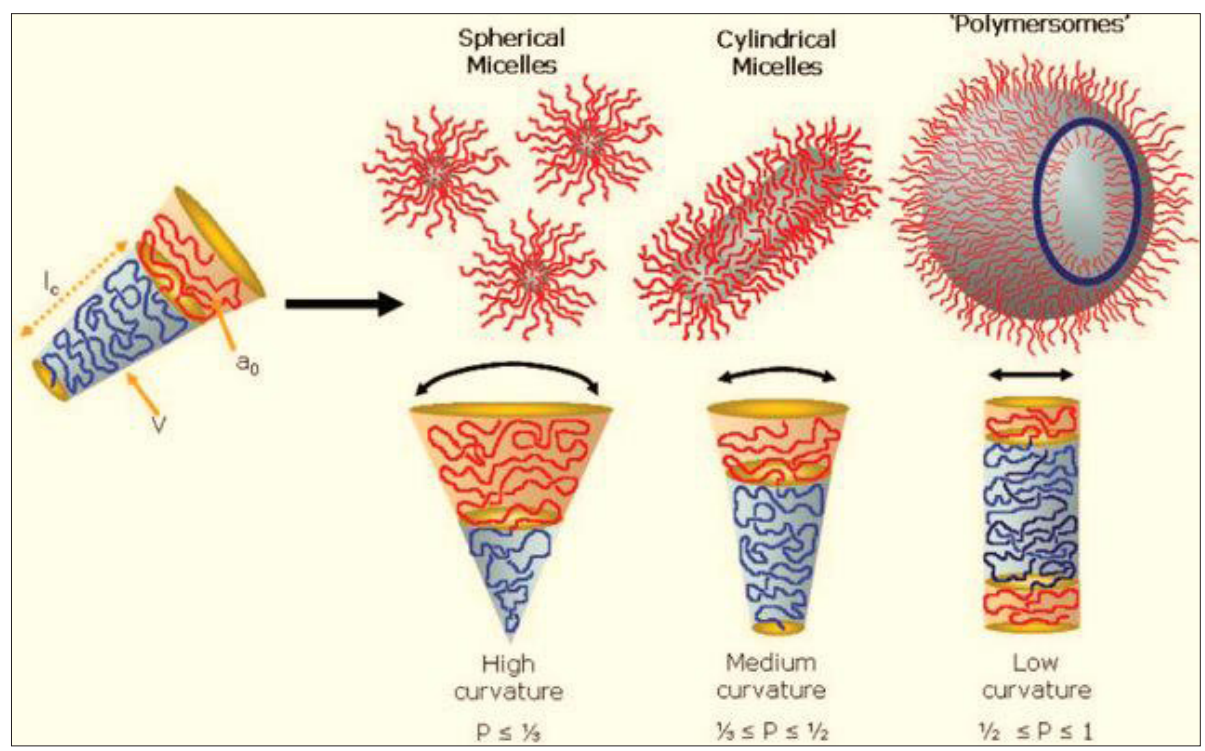

Fig. 11. The nanostructures of amphiphilic diblock copolymers for extraction lead ions

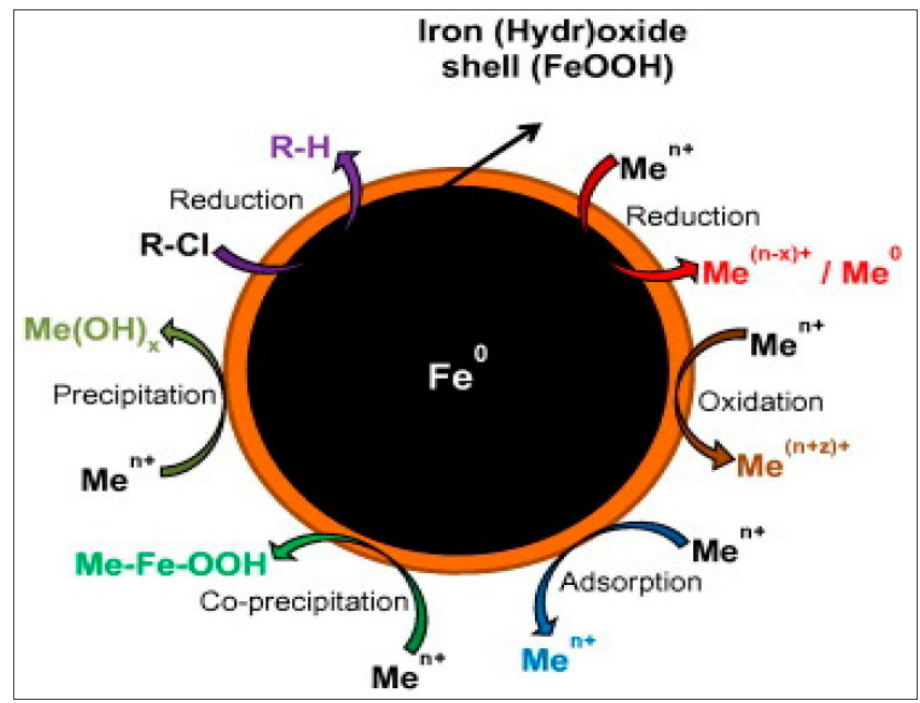

Fig. 12. The core-shell structure of nZVI used for extraction of metals [231] 


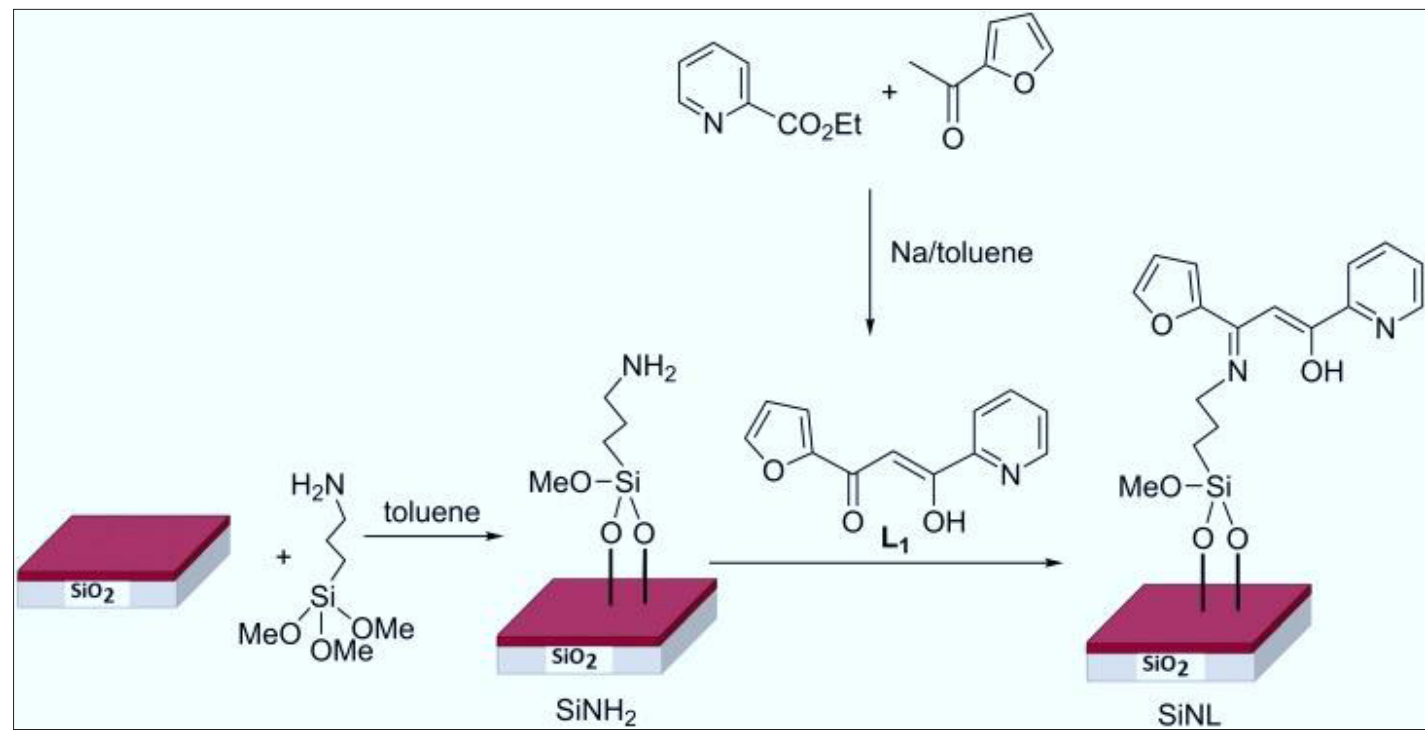

Scheme 4. The Silica nanoparticles based on $\beta$-ketoenol-pyridine-furan as chelating agent for extraction heavy metals in liquid phase

of separation, preconcentration, and extraction of heavy metals from water, waste water, vegetable and human biologic samples. Recently, the SPE methods were coupled with spectrometry techniques such as atomic absorption spectrometry (AAS) based on various adsorbents included graphene, graphene oxide, activated carbon, carbon nanotubes (CNTs), zeolites, MOF, magnetic nanoparticles, carbon quantum dots (CQDs)a nd MSN which was used for ultra-trace determination of heavy metals in different matrixes. In addition, the liquid-liquid micro extraction techniques coupled with ET-AAS, F-AAS, ATF-AAS, SQT-FAAS, ICP-XRF, CVAAS, ICP,ICP-AES, ICP-MS, ICP-OES, HPLC, voltammetry, UV-VIS, and FTIR were presented in this study by a lot of researchers. The proposed review showed us, the novel techniques based on nanotechnology had been developed in SPE and LLE methods since 2010 by authors. Also, SPE and solvent extraction based on different adsorbents and instrumental techniques were extended in various sciences such as, bio chemistry, nanotechnology, environmental analytical chemistry and human analysis during last decade.

\section{References}

[1] M.H. Dehghani, B. Heibati, A. Asadi, I. Tyagi, S. Agarwal, V.K. Gupta, Reduction of noxious Cr(VI) ion to $\mathrm{Cr}(\mathrm{III})$ ion in aqueous solutions using $\mathrm{H}_{2} \mathrm{O}_{2}$ and $\mathrm{UV} / \mathrm{H}_{2} \mathrm{O}_{2}$ systems, J. Ind. Eng. Chem., 33 (2016) 197-200.

[2] Cárdenas Valdivia, M. M. López Guerrero, E. I. Vereda Alonso, J. M. Cano Pavón, A. García de Torres, Determination of $\mathrm{As}, \mathrm{Sb}$, and $\mathrm{Hg}$ in water samples by flow injection coupled HR CS ETAAS with an in situ hydride generator, Microchem. J., 138 (2018) 109-115.

[3] S. Carballo, J. Terán, R. M. Soto, A. Carlosena, D. Prada, Green approaches to determine metals in lubricating oils by electrothermal atomic absorption spectrometry (ET-AAS), Microchem. J., 108 (2013) 74-80.

[4] M. Felipe-Sotelo, A. Carlosena, J. M. Andrade, M. J. Cal-Prieto, D. Prada, Slurry-based procedures to determine chromium, nickel and vanadium in complex matrices by ET-AAS, Microchem. J., 81 (2005) 217-224.

[5] G. Carrone, E. Morzan, M. Tudino, R. Etcheniqu, Determination of cadmium in commercial tobacco by ET-AAS, J. Anal. At. Spectrom., 33 (2018) 1970-1973.

[6] H. Ashkenani, M. A. Taher, Use of ionic liquid in simultaneous microextraction procedure for determination of gold and silver by ET-AAS, Microchem. J., 103 (2012) 185-190.

[7] I. Mohammadpourfard, N. Shariatifar, G. R. JahedKhaniki, E. Ebadi-Fathabad, Determination of Heavy Metals in Apricot and Almond Oils, Iran. J. Health Sci., 3 (2015) 18-24.

[8]A. Prkić, I. Mitar, J. Giljanović, V. Sokol, P. Bošković, 
I. Dolanc, T. Vukušić, Comparison of Potentiometric and ETAAS Determination of Copper and Iron in Herbal Samples, Int. J. Electrochem. Sci., 13 (2018) $9551-9560$.

[9] G. M. dos Santos, D. Pozebon, C. Cerveira, D. P. de Moraes, Inorganic arsenic speciation in rice products using selective hydride generation and atomic absorption spectrometry (AAS), Microchem. J., 133 (2017) 265-271.

[10] M. Balali-Mood, B. Riahi-Zanjani, A. Mahdizadeh, V. Moradi, R. FazeliBakhtiyari, Arsenic and lead contaminations in commercial fruit juices of markets in mashhad, Iran, Iran. J. Toxicol., 12 (2018) 15-20.

[11] S. Deniz, A. Kasa, S. Sel, Ç. Büyükpınar. S. Bakırdere, Sensitive and Accurate Determination of Cobalt at Trace Levels by Slotted Quartz TubeFlame Atomic Absorption Spectrometry Following Preconcentration with Dispersive Liquid-Liquid Microextraction, Anal. Lett., 52 (2019) 745-753

[12] P. Pohl, M. Kalinka, M. Pieprz, Development of a very simple and fast analytical methodology for FAAS/FAES measurements of $\mathrm{Ca}, \mathrm{K}, \mathrm{Mg}$ and $\mathrm{Na}$ in red beetroot juices along with chemical fractionation of $\mathrm{Ca}$ and $\mathrm{Mg}$ by solid phase extraction, Microchem. J., 147 (2019) 538-544.

[13] T. Daşbaşi, H. Muğlu, C. Soykan. A. Ülgen, Using a new synthesized polymer resin in various water and dried vegetables amples, J. Macromolecul. Sci., Part A, 55 (2018) 288-295

[14] E. Rossi, M. I. Errea, M. M. F. de Cortalezzi, J. Stripeikis, Selective determination of $\mathrm{Cr}$ (VI) by on-line solid phase extraction FI-SPE-FAAS using an ion exchanger resin as sorbent: An improvement treatment of the analytical signal, Microchem. J., 130 (2017) 88-92.

[15] P. Pohl, A. Dzimitrowicz, P. Jamroz, K. Greda, HRCS FAAS based method for direct determination of total concentrations of $\mathrm{Ca}, \mathrm{Fe}, \mathrm{Mg}$ and $\mathrm{Mn}$ in functional apple beverages and evaluation of contributions of the bioaccessible fraction of these elements by in vitro gastrointestinal digestion and chemical fractionation, Microchem. J., 140 (2018) 248-255.

[16] N. Bader, H. Hasan, A. EL-Denali, Determination of $\mathrm{Cu}, \mathrm{Co}$, and $\mathrm{Pb}$ in selected frozen fish tissues collected from Benghazi markets in Libya, Chem. Methodol., 2 (2018) 56-63

[17] A. Turek, K. Wieczorek, W.M. Wolf, Digestion Procedure and Determination of Heavy Metals in Sewage Sludge-An Analytical Problem,
Sustainability, 11 (2019) 1753.

[18] L. A. Meira, F. S. Dias, Application of constrained mixture design and Doehlert matrix in the optimization of dispersive liquid-liquid microextraction assisted by ultrasound for preconcentration and determination of cadmium in sediment and water samples by FAAS, Microchem. J., 130 (2017) 56-63.

[19] E. Mohammed, T. Mohammed, A. Mohammed, Optimization of instrument conditions for the analysis for mercury, arsenic, antimony and selenium by atomic absorption spectroscopy, Method. X, 5 (2018) 824-833.

[20] X. Yu, C.Liu, Y. Guo, T. Deng, Speciation Analysis of Trace Arsenic, Mercury, Selenium and Antimony in Environmental and Biological Samples Based on Hyphenated Techniques, Molecul., 24 (2019) 926.

[21] O. Syta, L. Kępa, A. Mistewicz, C. Wesołowska, B. Wagner, In situ study of Limoges painted enamels by portable X-rayfluorescence supported by laser ablation inductively coupled plasma mass spectrometry analysis of micro-samples, Microchem. J., 137 (2018) 37-44.

[22] P. R. Aranda, S. Moyano, L. D. Martinez, I. E. De Vito, Determination of trace chromium(VI) in drinking water using X-ray fluorescence spectrometry after solid-phase extraction, Anal. Bioanal. Chem., 398 (2010)1043-104

[23] P. Chauhan, R. P. Chauhan, M. Gupta, Estimation of naturally occurring radionuclides in fertilizers using gamma spectrometry and elemental analysis by XRF and XRD techniques, Microchem. J., 106 (2013) 73-78.

[24] L. M. Smieska, J. Twilley, A. R. Woll, M. Schafer, A. M. DeGalan, Energy-optimized synchrotron $X R F$ mapping of an obscured painting beneath Exit from the Theater, attributed to Honoré Daumier, Microchem. J., 146 (2019) 679-691.

[25] J. Barek, A. Berka, V. Borek, The use of redox reactions in the analysis of dyes and dye intermediates: XIV. Direct current polarography of 4,4'-disubstituted azobenzenes in acetonitrile, Microchem. J., 30 (1984) 404-417.

[26] O. Meena, A. Garg, Y. Kumar, R. Pandey, Electro analytical Procedure for determination of Heavy Metals in Brassica oleraceae ver. Botrytis, Int. J. Chem. Tech. Res. 3 (2011)1596-1603

[27] J. C. García-Mesa, P. Montoro Leal, M. M López Guerrero, E. I. Vereda Alonso, Simultaneous determination of noble metals, $\mathrm{Sb}$ and $\mathrm{Hg}$ by 
magnetic solid phase extraction on line ICPOES based on a new functionalized magnetic graphene oxide, Microchem. J., 150 (2019) 104141.

[28] Y. Yamini, M. Safari, Modified magnetic nanoparticles with catechol as a selective sorbent for magnetic solid phase extraction of ultra-trace amounts of heavy metals in water and fruit samples followed by flow injection ICP-OES, Microchem. J., 145 (2018) 503-511.

[29] J. Pérez-Arantegui, M. Resano, E. García-Ruiz, F. Vanhaecke, J. Coll, Characterization of cobalt pigments found in traditional Valencian ceramics by means of laser ablation-inductively coupled plasma mass spectrometry and portable X-ray fluorescence spectrometry, Talanta, 74 (2008) 1271-1280.

[30] P. Krystek, P. Favaro, P. Bode, R. Ritsema, Methyl mercury in nail clippings in relation to fish consumption analysis with gas chromatography coupled to inductively coupled plasma mass spectrometry: A first orientation, Talanta, 97 (2012) 83-86.

[31] B. N. Kumar, S. Kanchi, M.I. Sabela, K. Bisetty, N.V.V. Jyothi, Spectrophotometric determination of nickel (II) in waters and soils: Novel chelating agents and their biological applications supported by DFT method (UV-VIS), Karbala Int. J. Modern Sci., 2 (2016) 239-250

[32] W. Maher, M. Ellwood, S. Foster, G. Raber, Overview of hyphenated techniques using an ICP-MS detector with an emphasis on extraction techniques for measurement of metalloids by HPLC-ICPMS, Microchem. J., 105 (2012) 15-31.

[33] V. Majidi, Capillary electrophoresis inductively coupled plasma mass spectrometry, Microchem. J., 66 (2000) 3-16.

[34] Z. Stojanović, Z. Koudelkova, E. Sedlackova, D. Hynek, L. Richtera, V. Adam, Determination of chromium(vI) by anodic stripping voltammetry using a silver-plated glassy carbon electrode, Anal. Method., 10 (2018) 29172923.

[35] N. Mouhamed, K. Cheikhou, G. Elhadji Momar Rokhy, D. M. Bagha, M. D. C. Guèye, T. Tzedakis, Determination of lead in water by linear sweep anodic stripping voltammetry (LSASV) at unmodified carbon paste electrode: Optimization of operating parameters, Am. J. Anal. Chem., 9 (2018) $171-186$

[36] M. Alrobaian, H. Arida, Assessment of Heavy and
Toxic Metals in the Blood and Hair of Saudi Arabia Smokers Using Modern Analytical Techniques, Inter. J. Anal. Chem., 8 (2019) 1-8.

[37] A. J. Zimmerman, C. D. Weindorf, Heavy Metal and Trace Metal Analysis in Soil by Sequential Extraction: A Review of Procedures, Inter. J. Anal. Chem., 9 (2010) 1-7.

[38] A. S. Zahidqureshi, N. Mahboob, N. Khuram, Determination of Heavy Metal Toxicity in Blood and Health Effect by AAS (Detection of Heavy Metals and its Toxicity in Human Blood) Madiha Batool, Arch. Nano. Op. Acc. J., 1 (2018) 22-28.

[39] Y. Fu, Adsorption of Heavy Metal Sewage on Nanomaterials such as Titanate/TiO2Added Lignin, Results in Physics, 7 (2018) 5-17.

[40] Y. Zhang, W. Bing, X. Hui, L. Hui, M. Wang, Y. He, B. Pan, Nanomaterials-enabled water and wastewater treatment, Nanoimpact., 3 (2016) 22 39.

[41] M. Tuzen, M. Soylak, Multiwalled carbon nanotubes for speciation of chromium in environmental samples, J. Hazard. Mater., 147 (2007) 219-225.

[42] M. Zendehdel, B. Shoshtari-Yeganeh, G. Cruciani, Removal of heavy metals and bacteria from aqueous solution by novel hydroxyapatite/zeolite nanocomposite, preparation, and characterization, J. Iran. Chem. Soc., 13 (2016) 1915-1930.

[43] Y. Ren, N. Yan, Q. Wen, Z. Fan, T. Wei, M. Zhang, J. $\mathrm{Ma}$, Graphene $/ \delta-\mathrm{MnO} 2$ composite as adsorbent for the removal of nickel ions from wastewater, Chem. Eng. J., 175 (2011) 1-7.

[44] I. Ojea-Jiménez, X. López, J. Arbiol, V. Puntes, Citrate-coated gold nanoparticles as smart scavengers for mercury (II) removal from polluted waters, ACS Nano, 6 (2012) 2253-2259.

[45] D. S. K. Peker, O. Turkoglu, M. Soylak, Dysprosium (III) hydroxide coprecipitation system for the separation and preconcentration of heavy metal contents of table salts and natural waters, J. Hazard. Mater., 143 (2007) 555-560.

[46] M. Hiraide, T. Ito, M. Baba, H. Kawaguchi, A. Mizuike, Multielement preconcentration of trace heavy metals in water by coprecipitation and flotation with indium hydroxide for inductively coupled plasma-atomic emission spectrometry, Anal. Chem., 52 (1980) 804-807.

[47] M. Soylak, Column preconcentration/separation and atomic absorption spectrometric determinations of some heavy metals in table salt samples using amberlite XAD-1180, Turkish J. Chem., 7 (2003) 
235-42.

[48] M. A. Akl, I. M. Kenawy, R. R. Lasheen, Organically modified silica gel and flame atomic absorption spectrometry: employment for separation and preconcentration of nine trace heavy metals for their determination in natural aqueous systems, Microchem. J., 78 (2004) 143-56.

[49] M. A. A. Akl, I. M. M. Kenawy, R. R. Lasheen, Organically modified silica gel and flame atomic absorption spectrometry: employment for separation and preconcentration of nine trace heavy metals for their determination in natural aqueous systems, Microchem. J., 78 (2004) 143-156.

[50] M. Tuzen, M. Soylak, Multi-element coprecipitation for separation and enrichment of heavy metal ions for their flame atomic absorption spectrometric determinations, J. Hazard. Mater., 162 (2009) 724729.

[51] M. Soylak, N. D. Erdogan, Copper (II)-rubeanic acid coprecipitation system for separationpreconcentration of trace metal ions in environmental samples for their flame atomic absorption spectrometric determinations, J. hazard. Mater., 137 (2016) 1035-1041.

[52] G. Li, Z. Zhao, J. Liu, G. Jiang, Effective heavy metal removal from aqueous systems by thiol functionalized magnetic mesoporous silica, J. Hazard. Mater., 192 (2011) 277-283.

[53] G. Li, K.H. Row, Utilization of deep eutectic solvents in dispersive liquid-liquid micro-extraction, TrAC Trends in Anal. Chem., 7 (2019) 115651.

[54] M. A. Hashim, S. Mukhopadhyay, J. N. Sahu, B. Sengupta, Remediation technologies for heavy metal contaminated groundwater, J. Environ. Manag., 92 (2011) 2355-2388.

[55] H. Kim, K. Baek, J. Lee, J. Iqbal, J. W. Yang, Comparison of separation methods of heavy metal from surfactant micellar solutions for the recovery of surfactant, Desalination, 191 (2006) 186-192.

[56] Y. Sang, F. Li, Q. Gu, C. Liang, J. Chen, Heavy metal-contaminated groundwater treatment by a novel nanofiber membrane, Desalination, 223 (2008) 349-360.

[57] P. A. Kobielska, A. J. Howarth, O. K. Farha, S. Nayak, Metal-organic frameworks for heavy metal removal from water, Coordination Chem. Reviews, 358 (2018) 92-107.

[58] E. Alonso, A. Santos, M. Callejón, J. C. Jiménez, Speciation as a screening tool for the determination of heavy metal surface water pollution in the
Guadiamar river basin, Chemosphere, 56 (2004) 561-570.

[59] S. Obiri, Determination of heavy metals in water from boreholes in Dumasi in the Wassa West District of western region of Republic of Ghana, Environ. Monitor. Assess., 130 (2007) 455-463.

[60] C. Riccardi, P. Di Filippo, D. Pomata, F. Incoronato, M. Di Basilio, M. P. Papini, S. Spicaglia, Characterization and distribution of petroleum hydrocarbons and heavy metals in groundwater from three Italian tank farms, Sci. Total Environ., 393 (2008) 50-63.

[61] M. A. Momodu, C. A. Anyakora, Heavy metal contamination of ground water: The Surulere case study, Res. J. Environ. Earth Sci., 2 (2010) 39-43.

[62] A. Rudnitskaya, A. Ehlert, A. Legin, Y. Vlasov, S. Büttgenbach, S. Multisensor, System on the basis of an array of non-specific chemical sensors and artificial neural networks for determination of inorganic pollutants in a model groundwater, Talanta, 55 (2001) 425-431.

[63] P. Kurup, C. Sullivan, R. Hannagan, S. Yu, H. Azimi, S. Robertson, D. Ryan, R. Nagarajan, T. Ponrathnam, G. Howe, A review of technologies for characterization of heavy metal contaminants, Indian Geotech. J., 47 (2017) 421-436.

[64] K.S. Yun, J. Gil, J. Kim, H.J. Kim, K.H. Kim, D. Park, J.Y. Kwak, H. Shin, K. Lee, J. Kwak, E.Yoon, A miniaturized low-power wireless remote environmental monitoring system using microfabricated electrochemical sensing electrodes, $12^{\text {th }}$ international conference on solid-state sensors, actuators and microsystems, Cat. No. 03TH8664, IEEE, 2003.

[65] B. Bansod, T. Kumar, R. Thakur, S. Rana, I. Singh, A review on various electrochemical techniques for heavy metal ions detection with different sensing platforms, Biosen. Bioelectron., 94 (2017) 443-455.

[66] N. M. Isa, A. Z. Aris, W. Y. Lim, W. N. A. W. Sulaiman, S. M. Praveena, Evaluation of heavy metal contamination in groundwater samples from Kapas Island, Terengganu, Malaysia, Arab. J. Geosci., 7 (2014) 1087-1100.

[67] M. Afzal, G. Shabir, S. Iqbal, T. Mustafa, Q. M. Khan, Z. M.Khalid, Assessment of heavy metal contamination in soil and groundwater at leather industrial area of Kasur, Pakistan, CLEAN-Soil Air Water, 42 (2014) 1133-1139.

[68] A. Joshi, T. C. Nagaiah, Nitrogen-doped carbon nanotubes for sensitive and selective determination 
of heavy metals, RSC Adv., 5 (2015) 105119105127.

[69] H. X. Zhao, W. Cai, D. Ha, H. Wan, P. Wang, The study on novel microelectrode array chips for the detection of heavy metals in water pollution, $\mathrm{J}$. Innovative Optic. Health Sci., 5 (2012), 1150002.

[70] C.S. Chapman, C.M. Van Den Berg, University of Liverpool, Electrochemical cell. U.S. Patent 8,277,618, 2012.

[71] J. Holmes, P. Pathirathna, P. Hashemi, Novel frontiers in voltammetric trace metal analysis: Towards real time, on-site, in situ measurements, TrAC Trends in Anal. Chem., 5 (2018) 5-11.

[72] M. Liu, G. Zhao, Y. Tang, Z. Yu, Y. Lei, M. Li, Y. Zhang, D. Li, A simple, stable and picomole level lead sensor fabricated on DNA-based carbon hybridized $\mathrm{TiO}_{2}$ nanotube arrays, Environ. Sci. Tech., 44 (2010) 4241-4246.

[73] M. Gutiérrez-Capitán, A. Baldi, C. JimenezJorquera, C. Fernández-Sánchez, R. Gomez, V. García, Stripping voltammetric detection of trace heavy metals using gold ultramicroelectrode arrays, IEEE, $9^{\text {th }}$ IberoAmerican congress on sensors, 1-4, 2014.

[74] W. G. Yelton, M. P. Siegal, National Technology and Engineering Solutions of Sandia LLC, Nanoelectrode array for electrochemical analysis, U.S. Patent 7 (2009) 469.

[75] A. Sar1, M. Tuzen, D. Citak, M. Soylak, Adsorption characteristics of $\mathrm{Cu}$ (II) and $\mathrm{Pb}$ (II) onto expanded perlite from aqueous solution, J. Hazard. Mater., 148 (2007) 387-394.

[76] A. Sarı, M. Tuzen, Ö. D. Uluözlü, M. Soylak, Biosorption of $\mathrm{Pb} \quad$ (II) and $\mathrm{Ni}$ (II) from aqueous solution by lichen (Cladonia furcata) biomass, Biochem. Eng. J., 37 (2007) 151-158.

[77] O. D. Uluozlu, M. Tuzen, D. Mendil, M. Soylak, Trace metal content in nine species of fish from the Black and Aegean Seas, Turkey, Food chemistry, 104 (2007) 835-840.

[78] A. Sar1, M. Tuzen, M. Soylak, Adsorption of Pb (II) and $\mathrm{Cr}$ (III) from aqueous solution on Celtek clay, J. Hazard. Mater., 144 (2007) 41-46.

[79] M. Tuzen, K. O. Saygi, Usta C., Soylak M., Pseudomonas aeruginosa immobilized multiwalled carbon nanotubes as biosorbent for heavy metal ions, Biores. Tech., 99 (2008) 1563-1570.

[80] İ. Narin, M. Soylak, L. Elçi, M. Doğan, Determination of trace metal ions by AAS in natural water samples after preconcentration of pyrocatechol violet complexes on an activated carbon column, Talanta, 52 (2000) 1041-1046.

[81] M. Tuzen, M. Soylak, L. Elci, Multi-element preconcentration of heavy metal ions by solid phase extraction on Chromosorb 108, Analytica Chimica Acta, 548 (2005)101-108.

[82] U. Divrikli, N. Horzum, M. Soylak, L. Elci, Trace heavy metal contents of some spices and herbal plants from western Anatolia, Turkey, Int. J. food Sci. Tech., 41 (2006) 712-716.

[83] C. Duran, A. Gundogdu, V. N. Bulut, M. Soylak, L. Elci, H. B. Sentürk, M. Tüfekci, Solid-phase extraction of Mn (II), Co (II), Ni (II), Cu (II), Cd (II) and $\mathrm{Pb}$ (II) ions from environmental samples by flame atomic absorption spectrometry (FAAS), J. Hazard. Mater., 146 (2007) 347-355.

[84] A. Sari, D. Mendil, M. Tuzen, M. Soylak, Biosorption of palladium (II) from aqueous solution by moss (Racomitrium lanuginosum) biomass: Equilibrium, kinetic and thermodynamic studies, J. Hazard. Mater., 162 (2009) 874-879.

[85] D. Mendil, Ö. F. Ünal, M. Tüzen, M. Soylak, Determination of trace metals in different fish species and sediments from the River Yeşilırmak in Tokat, Turkey, Food Chem. Toxicol., 48 (2010) 1383-1392.

[86] A. Gundogdu, D. Ozdes, C. Duran, V. N. Bulut, M. Soylak, H. B. Senturk, Biosorption of Pb (II) ions from aqueous solution by pine bark (Pinus brutia Ten.), Chem. Eng. J., 153 (2009) 62-69.

[87] F. A. Aydin, M. Soylak, A novel multi-element coprecipitation technique for separation and enrichment of metal ions in environmental samples, Talanta, 73 (2007) 134-141.

[88] M. Tuzen, I. Karaman, D. Citak, M. Soylak, Mercury (II) and methyl mercury determinations in water and fish samples by using solid phase extraction and cold vapour atomic absorption spectrometry combination, Food Chem. Toxicol., 47 (2009) 1648-1652.

[89] M. Tuzen, D. Çıtak, D. Mendil, M. Soylak, Arsenic speciation in natural water samples by coprecipitation-hydride generation atomic absorption spectrometry combination, Talanta, 78 (2009) 52-56.

[90] M. Tuzen, K. O. Saygi, M. Soylak, Novel solid phase extraction procedure for gold (III) on Dowex M 4195 prior to its flame atomic absorption spectrometric determination, J. Hazard. Mater., 156 (2008) 591-595. 
[91] M. Tuzen, A. Sarı, D. Mendil, O. D. Uluozlu, M. Soylak, M. Dogan, Characterization of biosorption process of As (III) on green algae Ulothrix cylindricum, J. Hazard. Mater., 165 (2009) 566572.

[92] M. Soylak, O. Ercan, Selective separation and preconcentration of copper (II) in environmental samples by the solid phase extraction on multiwalled carbon nanotubes, J. Hazard. Mater., 168 (2009) 1527-1531.

[93] S. Saracoglu, M. Soylak, L. Elci, Separation/ preconcentration of trace heavy metals in urine, sediment and dialysis concentrates by coprecipitation with samarium hydroxide for atomic absorption spectrometry, Talanta, 59 (2003) 287-293.

[94] T. W. Speir, A. P. Van Schaik, H. J. Percival, M. E. Close, L. Pang, Heavy metals in soil, plants, and groundwater following high-rate sewage sludge application to land, J. Water, Air, Soil Poll., 150 (2003) 319-358.

[95] P. J. H. Scheeren, R. O. Koch, C. J. N. Buisman, L. J. Barnes, J. H. Versteegh, New biological treatment plant for heavy metal contaminated groundwater, In EMC'91:Non-merrous metallurgy, Springer, 9 (2007) 403-416.

[96] H. Malassa, F. Al-Rimawi, M. Al-Khatib, M. AlQutob, Determination of trace heavy metals in harvested rainwater used for drinking in Hebron (south West Bank, Palestine) by ICP-MS, Environ. Monitor. Assess., 186 (2014) 6985-6992.

[97] M. G. Yalcin, I. Narin, M. Soylak, Heavy metal contents of the Karasu creek sediments, Nigde, Turkey, Environ. Monitor. Assess., 128 (2007) 351357.

[98] O. D. Uluozlu, M. Tuzen, D. Mendil, M. Soylak, Determination of As (III) and As (V) species in some natural water and food samples by solid-phase extraction on Streptococcus pyogenes immobilized on Sepabeads SP 70 and hydride generation atomic absorption spectrometry, Food Chem. Toxicol., 48 (2010) 1393-1398.

[99] D. Mendil, F. Celik, M. Tuzen, M. Soylak, Assessment of trace metal levels in some moss and lichen samples collected from near the motorway in Turkey, J. Hazard. Mater., 166 (2009) 1344-1350.

[100] M. Tuzen, M. Soylak, K. Parlar, Cadmium and lead contamination in tap water samples from Tokat, Turkey, Bull. Environ. Conta. Toxicol., 75 (2005) 284-289.
[101] M. Tuzen and M. Soylak, Evaluation of Metal Levels of Drinking Waters from the Tokat-Black Sea Region of Turkey, Polish J. Environ. Studies, 15 (2006) 1-6.

[102] B. Naeemullaha, M. Tuzena, A new portable switchable hydrophilicity microextraction method for determination of vanadium in microsampling micropipette tip syringe system couple with ETAAS, Talanta, 5 (2018) 1-8.

[103] P. G. Jessop, L. Phan, A. Carrier, S. Robinson, C. J. Dürr, J. R. Harjani, A solvent having switchable hydrophilicity, Green Chem., 12 (2010) 809-814.

[104] E. Kazemi, S. Dadfarnia, A. M. Haji Shabani, P. Sadat Hashemi, Synthesis of 2-mercaptobenzothiazole/magnetic nanoparticles modified multi-walled carbon nanotubes for simultaneous solid-phase microextraction of cadmium and lead, Int. J. Environ. Anal. Chem., 97 (2017) 743-755.

[105] H. Heidari, A. Moghimi, H. R. Shahbazi, Solid phase extraction of trace cobalt ( II ) in industrial wastewaters by modified nanotube carbon carboxyl and its determination with flame atomic spectroscopy, Int. J. Bio-Inorg., 7 (2018) 43-57.

[106] Feist B., Selective dispersive micro solid-phase extraction using oxidized multiwalled carbon nanotubes modified with 1,10-phenanthroline for preconcentration of lead ions, Food Chem., 209 (2016) 37-42.

107] E. Zolfonoun, Solid phase extraction and determination of indium using multi-walled carbon nanotubes modified with magnetic nanoparticles, Anal. Meth. Environ. Chem. J., 1 (2018) 5-10.

[108] H. Shirkhanloo, A. Khaligh, H. Z. Mousavi, A. Rashidi, Ultrasound assisted-dispersive-ionic liquid-micro-solid phase extraction based on carboxyl-functionalized nanoporous graphene for speciation and determination of trace inorganic and organic mercury species in water and caprine blood samples, Microchem. J., 130 (2017) 245-254.

[109] H. Shirkhanloo, M. Ghazaghi, A. Rashidi, A. Vahid, Arsenic speciation based on amine-functionalized bimodal mesoporous silica nanoparticles by ultrasound assisted-dispersive solid-liquid multiple phase microextraction, Microchem. J., 130 (2017) 137-146.

110] M. Tuzen, A new robust, deep eutectic-based floating organic droplets microextraction method for determination of lead in a portable syringe 
system directly couple with FAAS, Talanta, 196 (2019) 71-77.

[111] R. A. Zounr, M. Tuzen, N. Deligonul, M.Y. Khuhawar, A highly selective and sensitive ultrasonic assisted dispersive liquid phase microextraction based on deep eutectic solvent for determination of cadmium in food and water samples prior to electrothermal atomic absorption spectrometry, Food Chem., 253 (2018) 277-283.

[112] M. Tuzen, O.D. Uluozlu, D. Mendil, M. Soylak, L.O.R. Machado, W.N.L. DosSantos, S.L.C. Ferreira, A simple, rapid and green ultrasound assisted and ionic liquid dispersive microextraction procedure for the determination of tin in foods employing ETAAS, Food Chem., 254 (2018) 380384.

[113] S. Moyano, G. Polla, P. Smichowski, J.A. Gásquez, L.D. Martinez, On-line preconcentration and determination of vanadium in tap and river water samples by flow injection-inductively coupled plasma-optical emission spectrometry (FI-ICPOES), J. Anal. At. Spectrom., 21 (2006) 422-426.

[114] T. Stefanova-Bahchevanska, N. Milcheva, S. Zaruba, V. Andruch, V. Delchev, K. Simitchiev, Gavazov K. A., green cloud-point extractionchromogenic system for vanadium determination, $\mathrm{J}$. Mol. Liq., 248 (2017) 135-142.

[115] I. López-García, J.M.H. Juan, H.C. Manuel, Graphite furnace atomic absorption spectrometric determination of vanadium after cloud point extraction in the presence of graphene oxide, Spectrochim. Acta Part B, 143 (2018) 42-47.

[116] S. Khan, T.G. Kazi, J.A. Baig, N.F. Kolachi, H.I. Afridi, S.K. Wadhwa, F. Shah, Cloudpoint extraction of vanadium in pharmaceutical formulations, dialysate and parenteral solutions using 8-hydroxyquinoline and nonionic surfactant, J. Hazard. Mater., 182 (2010) 371-376.

[117] T. Asadollahi, S. Dadfarnia, A. M. H. Shabani, Separation/preconcentration and determination of vanadium with dispersive liquid-liquid microextraction based on solidification of floating organic drop (DLLME-SFO) and electrothermal atomic absorption spectrometry, Talanta, 82 (2010) 208-212.

[118] L. Chen, H. Xin, Y. Fang, Application of metal oxide heterostructures in arsenic removal from contaminated water, J. Nanomater., 2 (2014) 1-10.

[119] M.K. Ghosh, G.E.J. Poinern, T.B. Issa, ‘Arsenic adsorption on goethite nanoparticles produced through hydrazine sulfate assisted synthesis method', Korean J. Chem. Eng., 29 (2012) 95-102.

[120] L. Feng, M. Cao, X. Ma, Superparamagnetic highsurface-area $\mathrm{Fe}_{3} \mathrm{O}_{4}$ nanoparticles as adsorbents for arsenic removal, J. Hazard. Mater., 217 (2012) 439-446.

[121] W. Tang, Y. Su, Q. Li, Mg-doping: a facile approach to impart enhanced arsenic adsorption performance and easy magnetic separation capability to alphaFe2O3 nanoadsorbents, J. Mater. Chem. A, 1 (2013) $830-836$

[122] D. Nabi, I. Aslam, I. A. Qazie, Evaluation of the adsorption potential of titanium dioxide nanoparticles for arsenic removal, J. Environ. Sci., 21 (2009) 402-408.

[123] M. I. Danish, I. A. Qazi, A. Zeb, Arsenic removal from aqueous solution using pure and metaldoped titania nanoparticles coated on glass beads: adsorption and column studies, J. Nanomater., 69 (2013) 1-17.

[124] C.A. Martinson, K.J. Reddy, 'Adsorption of arsenic(III) and arsenic(V) by cupric oxide nanoparticles', J. Colloid Interf. Sci., 336 (2009) 406- 411 .

[125] R. Li, Q. Li, S. Gao, Exceptional arsenic adsorption performance of hydrous cerium oxide nanoparticles: Part A. Adsorption capacity and mechanism, Chem. Eng. J., 185 (2012) 127-135.

[126] Y. Liu, Q. Li, S. Gao, Exceptional As(III) sorption capacity by highly porous magnesium oxide nanoflakes made from hydrothermal synthesis, J. Am. Ceram. Soc., 94 (2011) 217-223.

[127] A. Goswami, P. K. Raul, M. K. Purkait, Arsenic adsorption using copper (II) oxide nanoparticles, Chem. Eng. Res. Des., 90 (2012) 1387-1396.

[128] H. Cui, Q. Li, S. Gao, Strong adsorption of arsenic species by amorphous zirconium oxide nanoparticles', J. Ind. Eng. Chem., 18 (2012) 1418 1427.

[129] S. A. Ntim, S. Mitra, Adsorption of arsenic on multiwall carbon nanotubezirconia nanohybrid for potential drinking water purification, J. Colloid Interf. Sci., 375 (2012) 154-159.

[130] R. Chen, C. Zhi, H. Yang, Arsenic(V) adsorption on $\mathrm{Fe}_{3} \mathrm{O}_{4}$ nanoparticle-coated boron nitride nanotubes', J. Colloid Interf. Sci., 359 (2011) 261-268.

[131] W. Yang, P. Ding, L. Zhou, Preparation of diamine modified mesoporous silica on multi-walled carbon nanotubes for the adsorption of heavy metals in aqueous solution, Appl. Surf. Sci., 23 (2013) 38-45. 
[132] Y. M. Hao, C. Man, Z. B. Hu, Effective removal of $\mathrm{Cu}^{2+}$ ions from aqueous solution by aminofunctionalized magnetic nanoparticles, J. Hazard. Mater., 184 (2014) 392-399.

[133] Y. T. Zhou, H. L. Nie, C. B. White, Removal of $\mathrm{Cu}^{2+}$ from aqueous solution by chitosan-coated magnetic nanoparticles modified with aketoglutaric acid, J. Colloid Interf. Sci., 330 (2009) 29-37.

[134] M. A. Salam, M. S. I. Makki, M. Y. A. Abdelaal, Preparation and characterization of multi-walled carbon nanotubes/chitosan nanocomposite and its application for the removal of heavy metals from aqueous solution', J. Alloy. Compd., 509 (2009) 2582-2587.

[135] O. Hakami, Y. Zhang, Banks C. J., Thiolfunctionalised mesoporous silicacoated magnetite nanoparticles for high efficiency removal and recovery of $\mathrm{Hg}$ from water, Water Res., 46 (2012) 3913-3922.

[136] A. Farrukh, A. Akram, A. Ghaffar, Design of polymer-brush-grafted magnetic nanoparticles for highly efficient water remediation, ACS Appl. Mater. Interf., 5 (2013) 3784-3793.

[137] B. Tawabini, S. Al-Khaldi, M. Atieh, Removal of mercury from water by multi-walled carbon nanotubes, Water Sci. Technol., 61 (2010) 591-598.

[138] F. A. Al-Khaldi, B. Abu-Sharkh, A. M. Abulkibash, Cadmium removal by activated carbon, carbon nanotubes, carbon nanofibers, and carbon fly ash: a comparative study, Desalination Water Treat., 53 (2015) 1417-1429.

[139] F. P. Fato, D. W. Li, L. Zhao, K. Qiu, Simultaneous Removal of Multiple Heavy Metal Ions from River Water Using Ultrafine Mesoporous Magnetite Nanoparticles, ACS Omega, 44 (2019) 7543-7549.

[140] G. Gollavelli, C. C. Chang, Y. C. Ling, Facile Synthesis of Smart Magnetic Graphene for Safe Drinking Water: Heavy Metal Removal and Disinfection Control, ACS Sustainable Chem. Eng., 1 (2013) 462-472.

[141] X. Luo, J. Zeng, S. Liu, L. Zhang, An effective and recyclable adsorbent for the removal of heavy metal ions from aqueous system: magnetic chitosan/ cellulose microspheres, Bioresour. Technol., 8 (2015) 135-142.

[142] M. Mahmoudi, S. Sant, B. Wang, S. Laurent, T. Sen, Superparamagnetic iron oxide nanoparticles (SPIONs): development, surface modification and applications in chemotherapy, Adv. Drug. Delivery Rev., 63 (2011) 24-46.
[143] N. Neyaz, W. Siddiqui, K. Nair, Application of surface functionalized iron oxide nanomaterials as a nanosorbents in extraction of toxic heavy metals from ground water: A review, Int. J. Environ. Sci., 4 (2013) 472-483.

[144] F. H. Chen, Q. Gao, J. Z. Ni, The grafting and release behavior of doxorubincin from $\mathrm{Fe}_{3} \mathrm{O}_{4}$ at $\mathrm{SiO} 2$ core-shell structure nanoparticles via an acid cleaving amide bond: the potential for magnetic targeting drug delivery, Nanotechnol., 19 (2008) 165103.

[145] X. Luo, X. Lei, N. Cai, X. Xie, Y. Xue, F. Yu, Removal of Heavy Metal Ions from Water by Magnetic Cellulose-Based Beads with Embedded Chemically Modified Magnetite Nanoparticles and Activated Carbon, ACS Sustainable Chem. Eng., 47 (2016) 3960-3969.

[146] M. A. Shannon, Science and technology for water purification in the coming decades, Nanosci. Technol., 452 (2008) 301-310.

[147] X. Luo, L. Zhang, Immobilization of Penicillin G Acylase in Epoxy-Activated Magnetic Cellulose Microspheres for Improvement of Biocatalytic Stability and Activities. Biomacromolecules, 11 (2010) 2896-2903.

[148] M. Gericke, J. Trygg, P. Fardim, Functional Cellulose Beads: Preparation, Characterization, and Applications, Chem. Rev., 113 (2013) 4812-4836.

[149] H. Karami, Heavy metal removal from water by magnetite nanorods, Chem. Eng. J., 219 (2013) 209-216.

[150] Y. Zhao, H. Chen, J. Li, C. Chen, Hierarchical MWCNTs $/ \mathrm{Fe}_{3} \mathrm{O}_{4} / \mathrm{PANI}$ magnetic composite as adsorbent for methyl orange removal, J. Colloid Interface Sci., 450 (2015) 189-195.

[151] C. Santhosh, R. Nivetha, P. Kollu, V. Srivastava, M. Sillanpää, A. Nirmala Grace, A. Bhatnagar, Removal of cationic and anionic heavy metals from water by $1 \mathrm{D}$ and 2D-carbon structures decorated with magnetic nanoparticles, Sci. Rep., 7 (2017) 14100-14107.

[152] S. Singh, K. C. Barick, D. Bahadur, Functional Oxide Nanomaterials and Nanocomposites for the Removal of Heavy Metals and Dyes Invited Review Article, Nanomater. nanotechnol., 3 (2013) 1-18.

[153] P. Z. Ray, H. J. Shipley, Inorganic nano-adsorbents for the removal of heavy metals and arsenic: a review, RSC Adv., 5 (2015) 29885-29907.

[154] G. Vilardi, T. Mpouras, D. Dermatas, N. Verdone, A. Polydera, L. Di, Palma Nanomaterials application 
for heavy metals recovery from polluted water: the combination of nano zero-valent iron and carbon nanotubes. Competitive adsorption non-linear modeling, Chemosphere, 201 (2018) 716-729.

[155] M. Alrobaian and H. Arida, Assessment of Heavy and Toxic Metals in the Blood and Hair of Saudi Arabia Smokers Using Modern Analytical Techniques, Int. J. Anal. Chem., 14 (2019) 1-8.

[156] K. Liu, H. Qi, R. Dong, R. Shivhare, M. Addicoat, T. Zhang, H. Sahabudeen, T. Heine, S. Mannsfeld, U. Aiser, Z. Zheng, X. Feng, Onwater surface synthesis of crystalline, few-layer two-dimensional polymers assisted by surfactant monolayers, Nature Chem., 11 (2019) 994-1000

[157] M. Rosillo-Lopez, C. G. Salzmann, Highly efficient heavy-metal extraction from water with carboxylated graphene nanoflakes, RSC Adv., 8 (2018) 11043-11050.

[158] J. Zhao, X. Yan, T. Zhou, J. Wang, H. Li, P. Zhang, H. Ding, L. Ding, Multi-throughput dynamic microwave-assisted leaching coupled with inductively coupled plasma atomic emission spectrometry for heavy metal analysis in soil, $\mathbf{J}$. Anal. At. Spectrom., 30 (2015) 1920-1926

[159] A. P. Esser-Kahn, A. T. Iavarone, Matthew B. Francis, Metallothionein-Cross-Linked Hydrogels for the Selective Removal of Heavy Metals from Water, J. American Chem. Society, 130 (2008) $15820-15822$

[160] H. Shirkhanloo, A. Khaligh, H. Zavvar Mousavi, A. Rashidi, Ultrasound assisted-dispersive-micro-solid phase extraction based on bulky amino bimodal mesoporous silica nanoparticles for speciation of trace manganese (II)/(VII) ions in water samples, Microchem. J., 124 (2016) 637-645.

[161] H. Shirkhanloo, A. Khaligh, H. Zavvar Mousavi, A. Rashidi, Ultrasound assisted-dispersive-ionic liquid-micro-solid phase extraction based on carboxyl-functionalized nanoporous graphene for speciation and determination of trace inorganic and organic mercury species in water and caprine blood samples, Microchem. J., 130 (2017) 245-254

[162] H. Shirkhanloo, M. Ghazaghi, A. Rashidi, A. Vahid, Arsenic speciation based on amine-functionalized bimodal mesoporous silica nanoparticles by ultrasound assisted-dispersive solid-liquid multiple phase microextraction, Microchem. J., 130 (2017) 137-146.

[163] H. Shirkhanloo, M. Ghazaghi, H. Z. Mousavi, Chromium speciation in human blood samples based on acetylcysteine by dispersive liquid-liquid bio microextraction and in-vitro evaluation of acetyl cysteine/cysteine for decreasing of hexavalent chromium concentration, J. Pharmac. Biomed. Anal., 118 (2016) 1-8.

[164] H. Shirkhanloo, A. Khaligh, F. Golbabaei, Z. Sadeghi, A. Vahid, A. Rashidi, On-line micro column preconcentration system based on amino bimodal mesoporous silica nanoparticles as a novel adsorbent for removal and speciation of chromium (III, VI) in environmental samples, J. Environ. Health Sci. Eng., 13 (2015) 13-47.

[165] C. S. A. Felix, D. L. F. da Silva, A. V. B. Chagas, A green on-line digestion system using $70 \%$ hydrogen peroxide and UV radiation for the determination of chromium in beer employing ETAAS, Microchem. J., 146 (2019) 1204-1208.

[166] E. G. Barrera, D. Bazanella, P. W. Castro, W. Boschetti, M. B. Dessuy, Alternative method for chromium determination in pharmaceutical drugs by HR-CS GF AAS and direct analysis of solid samples, Microchem. J., 132 (2017) 365-370.

[167] L. Boutorabi, M. Rajabi, M. Barzegar, A. Asghari, Selective determination of chromium(VI) ions using in-tube electro-membrane extraction followed by flame atomic absorption spectrometry, Microchem. J., 132 (2017) 378-384.

[168] M. Shirani, F. Salari, S. Habibollahi, A. Akbari, Needle hub in-syringe solid phase extraction based a novel functionalized biopolyamide for simultaneous green separation/preconcentration and determination of cobalt, nickel, and chromium (III) in food and environmental samples with micro sampling flame atomic absorption spectrometry, Microchem. J., 132 (2019) 104332-104340.

[169] M. Felipe-Sotelo, A. Carlosena, J. M. Andrade, M. J. Cal-Prieto, D. Prada, Slurry-based procedures to determine chromium, nickel and vanadium in complex matrices by ETAAS, Microchem. J., 81 (2005) 217-224.

[170] R. Pechancová, T. Pluháček, J. Gallo, D. Milde, Study of chromium species release from metal implants in blood and joint effusion: Utilization of HPLC-ICP-MS, Talanta, 185 (2018) 370-377.

[171] E. Jorge, M. M. Rocha, I. T. E. Fonseca, M. M. M. Neto, Studies on the strippingvoltammetric determination and speciation of chromium at a rotating-discbismuth film electrode, Talanta, 81 (2010) 556-564. 
[172]D. Verma, S.K. Verma,M.K.Deb, Single-dropmicroextraction and diffusereflectance Fourier transform infrared spectroscopic determination of chromium in biological fluids, Talanta, 78 (2009) 270-277.

[173] M. Firat, S. Bakırdere, M. Selin Fındıkoğlu, E. Betül Kafa, E. Yazıcı, M. Yolcu, Ç. Büyükpınar, D. S. Chormey, S. Sel, F. Turak, Determination of trace amount of cadmium using dispersive liquid-liquid microextraction-slotted quartz tube-flame atomic absorption spectrometry, Spectrochim. Acta Part B At. Spectrosc., 129 (2017) 37-41.

[174] R. Gürkan, S. Korkmaz, N. Altunay, Preconcentration and determination of vanadium and molybdenum in milk, vegetables and foodstuffs by ultrasonic-thermostatic-assisted cloud point extraction coupled to flame atomic absorption spectrometry, Talanta, 155 (2016) 38-46.

[175] N. A. Kasa, S. Sel, D. S. Chormey, S. Bakırdere, Determination of cadmium at trace levels in parsley samples by slotted quartz tube-flame atomic absorption spectrometry after preconcentration with cloud point extraction, Measurement, 147 (2019) 106841.

[176]K. Shrivas, K.Dewangan, A.Ahmed, Surfactantbased dispersive liquid-liquid microextraction for the determination of zinc in environmental water samples using flame atomic absorption spectrometry, Anal. Meth., 8 (2016) 5519-5525.

[177] S. Deniz, A. Kasa, S. Sel, Ç. Büyükpınar, S. Bakırdere, Sensitive and accurate determination of cobalt at trace levels by slotted quartz tubeflame atomic absorption spectrometry following preconcentration with dispersive liquid-liquid microextraction, Anal. Lett., 17 (2019) 745-753.

[178] E. Yazıc1, M. Firat, S. Chormey, E. G. Bakırdere, S. Bakırdere, An accurate determination method for cobalt in sage tea and cobalamin: Slotted quartz tube-flame atomic absorption spectrometry after preconcentration with switchable liquidliquid microextraction using a Schiff base, Food Chem., 302 (2019) 125330-125336.

[179] A.T. Bisgin, Surfactant-Assisted Emulsification and Surfactant-Based Dispersive Liquid-Liquid Microextraction Method for Determination of $\mathrm{Cu}$ (II) in Food and Water Samples by Flame Atomic Absorption Spectrometry, J. AOAC Inter., 102 (2019) 1516-1522.

[180] A. M. Farajzadeh, H. Dastoori, S. M. Sorouraddin, Development of a dispersive liquid-liquid microextraction method based on a ternary deep eutectic solvent as chelating agent and extraction solvent for preconcentration of heavy metals from milk samples, Talanta, 193 (2019) 120485. [181] J. A. Barreto, R Santos de Assis, R. J. Cassella, V. Azevedolemos, A novel strategy based on insyringe dispersive liquid-liquid microextraction for the determination of nickel in chocolate samples, Author links open overlay panel, Talanta, 193 (2019) 23-28.

[182] E. Fernández, L. Vidal, A. C. García, A. Cana, Mercury determination in urine samples by gold nanostructured screen-printed carbon electrodes after vortex-assisted ionic liquid dispersive liquidliquid microextraction, Analytica. Chimica. Acta., 915 (2016) 49-55.

[183] H. Shirkhanloo, M. Ghazaghi, M. M. Eskandari, Cloud point assisted dispersive ionic liquid -liquid microextraction for chromium speciation in human blood samples based on isopropyl 2-[(isopropoxycarbothiolyl)disulfanyl] ethane thioate, Anal. Chem. Res., 10 (2016) 18-27.

[184] H. Shirkhanloo, M. Ghazaghi, H. ZavvarMousavi, Cadmium determination in human biological samples based on trioctylmethyl ammonium thiosalicylate as a task-specific ionic liquid by dispersive liquid-liquid microextraction method, J. Molec. Liqu., 218 (2016) 478-483.

[185] H. Z. Mousavi, H. Shirkhanloo, M. Ghazaghi, Chromium speciation in human blood samples based on acetylcysteine by dispersive liquid-liquid biomicroextraction and in-vitro evaluation of acetyl cysteine/cysteine for decreasing of hexavalent chromium concentration, J. Pharmac. Biomed. Anal., 118 (2016) 1-8.

[186] E. C. Lourenço, E. Eyng, P. R. S. Bittencourt, Fabio A. Duarte, Rochele S. Picoloto, É. L. M. Flores, A simple, rapid and low cost reversed-phase dispersive liquid-liquid microextraction for the determination of $\mathrm{Na}, \mathrm{K}, \mathrm{Ca}$ and $\mathrm{Mg}$ in biodiesel, Talanta, 199 (2019) 1-7.

[187] L. B. Escudero, P. Berton, E. M. Martinis, R. A. Olsina, R. G. Wuilloud, Dispersive liquid-liquid microextraction and preconcentration of thallium species in water samples by two ionic liquids applied as ion-pairing reagent and extractant phase, Talanta, 88 (2012) 277-283.

[188] X. Jia, Y. Han, C. Wei, T. Duan, H. Chen, Speciation of mercury in liquid cosmetic samples by ionic liquid based dispersive liquid-liquid 
microextraction combined with high-performance liquid chromatography inductively coupled plasma mass spectrometry, J. Anal. Atom. Spectrom., 26 (2011) 1380-1386.

[189] L. B. Escudero, E. M. Martinis, R. A. Olsina, R. G. Wuilloud, Arsenic speciation analysis in monovarietal wines by on-line ionic liquid-based dispersive liquid-liquid microextraction, Food Chem., 138 (2013) 484-490.

[190] J. F. Ayala-Cabrera, M. J. Trujillo-Rodríguez, V. Pino, Ó. M. Hernández-Torres, A. M. Afonso, J. Sirieix-Plénet, Ionic liquids versus ionic liquidbased surfactants in dispersive liquid-liquid microextraction for determining copper in water by flame atomic absorption spectrometry, Inter. J. Environ. Anal. Chem., 96 (2016) 101-118.

[191] E. Molaakbari, A. Mostafavi, D. Afzali, Ionic liquid ultrasound assisted dispersive liquid-liquid microextraction method for preconcentration of trace amounts of rhodium prior to flame atomic absorption spectrometry determination, J. Hazard. Mater., 185 (2011) 647-652.

[192] P. Berton, E.M. Martinis, L.D. Martinez, R.G. Wuilloud, Room temperature ionic liquid-based microextraction for vanadium species separation and determination in water samples by electrothermal atomic absorption spectrometry, Anal. Chim. Acta., 640 (2009) 40-46.

[193] M. Tuzen, O. Z. Pekiner, Ultrasound-assisted ionic liquid dispersive liquid-liquid microextraction combined with graphite furnace atomic absorption spectrometric for selenium speciation in foods and beverages, Food Chem., 188 (2015) 619-624.

[194] A. Beiraghi, M. Shokri, S. Seidi, B. M. Godajdar, Magnetomotive room temperature dicationic ionic liquid: A new concept toward centrifugeless dispersive liquid- liquid microextraction, J. Chromatogr. A, 76 (2015) 1-8.

[195] V. Balarama, K. Mullapudi, K. Chandrasekaran, G. Venkateswarlu, D. Karunasagar, Development of a simple and rapid microwave-assisted extraction method using very dilute solutions of perchloric acid and hydrogen peroxide for the multi-elemental analysis of food materials by ICP-OES: A green analytical method, Microchem. J., 146 (2019) 807817.

[196] E. J. Santos, S. Clarice, D. B. Amaral, N. Nagata, M. T. Grassi, Cloud point extractors for simultaneous determination of Pd and Pt in water samples by ICP OES with multivariate optimization, Microchem.
J., 152 (2020) 104300-104309.

[197] S. A. Arain, T. G. Kazi, H. I. Afridi, M. Shahzadi Arain, A. H. Panhwar, N. Khan, J. A. Baig, F. Shah, A new dispersive liquid-liquid microextraction using ionic liquid based microemulsion coupled with cloud point extraction for determination of copper in serum and water samples, Ecotoxicol. Environ. Safety, 126 (2016) 186-192.

[198] H. Shirkhanloo, M. Falahnejad, H. Zavvar Mousavi, On-line ultrasound-assisted dispersive micro-solid-phase extraction based on amino bimodal mesoporous silica nanoparticles for the preconcentration and determination of cadmium in human biological samples, Microchem. J., 124 (2016) 637-645.

[199] M. Ghazaghi, H. Zavvar Mousavi, A. M. Rashidi, H. Shirkhanloo, R. Rahighi, Graphene-silica hybrid inefficient preconcentration of heavy metal ions via novel single-step method of moderate centrifugation-assisted dispersive micro solid phase extraction, Talanta, 150 (2016) 476-484.

[200] M. Falahnejad, H. Zavvar Mousavi, H. Shirkhanloo, A.M. Rashidi, Preconcentration and separation of ultra-trace amounts of lead using ultrasoundassisted cloud point-micro solid phase extraction based on amine functionalized silica aerogel nanoadsorbent, 125 (2016) 236-241.

[201] H. Shirkhanloo, M. Ghazaghi, A. Rashidi, A. Vahid, Arsenic speciation based on amine-functionalized bimodal mesoporous silica nanoparticles by ultrasound assisted-dispersive solid-liquid multiple phase microextraction, Microchem. J., 130 (2017) 137-146.

[202] H. Shirkhanloo, A. Khaligh, H. Zavvar Mousavi, A. Rashidi, Ultrasound assisted-dispersive-ionic liquid-micro-solid phase extraction based on carboxyl-functionalized nanoporous graphene for speciation and determination of trace inorganic and organic mercury species in water and caprine blood samples, Microchem. J., 130 (2017) 245-254.

[203] H. Shirkhanloo, A. Khaligh, H. Zavvar Mousavi, A. Rashidi, Ultrasound assisted-dispersive-micro-solid phase extraction based on bulky amino bimodal mesoporous silica nanoparticles for speciation of trace manganese (II)/(VII) ions in water samples, Microchem. Journal 124 (2016) 637-645.

[204] F. Hosseini, H. Shirkhanloo, N. Motakef Kazemi, Nano analysis in biochemistry: in vitro separation and determination of aluminum in blood of dialysis patients based on graphene oxide nanoparticles 
dispersed to ionic liquid, J. Nanoanal., 4 (2017) 99109.

[205] S. Golkhah, H. Zavvar Mousavi, H. Shirkhanloo, A. Khaligh, Removal of $\mathrm{Pb}$ (II) and $\mathrm{Cu}$ (II) Ions from Aqueous Solutions by Cadmium Sulfide Nanoparticles, Int. J. Nanosci. Nanotechnol., 13 (2017) 105-117.

[206] Z. Ying, L. Chun-yan, Y. Jin-gang, J. Xin-yu, Adsorption properties of a novel 3D graphene/ $\mathrm{MgO}$ composite for heavy metal ions, J. Cent. South Univ., 26 (2019) 813-823.

[207] H. Shirkhanlooa, A. Khaligh, H. Zavvar Mousavi, Al. Rashidi, Graphene oxide-packed micro-column solid-phase extraction combined with flame atomic absorption spectrometry for determination of lead (II) and nickel (II) in water samples, Int. J. Environ. Anal. Chem., 95 (2014) 1-17.

[208] R. Sitko, P. Janik, B. Feist, E. Talik, A. Gagor, Suspended aminosilanized graphene oxide nanosheets for selective preconcentration of lead ions and ultrasensitive determination by electrothermal atomic absorption spectrometry, ACS Appl. Mater. Iinterfaces, 6 (2014) 20144-20153.

[209] A. Khaligh, H. Zavvar Mousavi, H. Shirkhanloo, A. Rashidi, Speciation and determination of inorganic arsenic species in water and biological samples by ultrasound assisted-dispersive-micro-solid phase extraction on carboxylated nanoporous graphene coupled with flow injection-hydride generation atomic absorption spectrometry, RSC Adv., 5 (2015) 93347-93359.

[210] M. Ghazaghi, H. Zavvar Mousavia, A. Rashidi, H. Shirkhanloo, R. Rahighi, Innovative separation and preconcentration technique of coagulating homogenous dispersive microsolid phase extraction exploiting graphene oxide nanosheets, Anal. Chim. Acta, 902 (2016) 33-42.

[211] B. Yang, Q. Gong, L. Zhao, H. Sun, N. Ren, J. Qin, J. Xu, H. Yang, Preconcentration and determination of lead and cadmium in water samples with $\mathrm{MnO} 2$ coated carbon nanotubes by using ET-AAS, Desalination, 278 (2011) 65.

[212] Z. Bahadir, V. Bulut, M. Hidalgo, M. Soylak, E. Marguí, Determination of trace amounts of hexavalent chromium in drinking waters by dispersive micro-solid phase extraction using modified multiwalled carbon nanotubes combined with total reflection X-ray fluorescence spectrometry, Spectrochim. Acta Part B, 107 (2015) $170-177$.
[213] C. Cui, H. Peng, Y. Zhang, K. Nan, M. He, B. Chen, B. Hu, Ti-containing meso- porous silica packed micro-column separation/preconcentration combined with inductively coupled plasma-mass spectrometry for the determination of trace $\mathrm{Cr}, \mathrm{Cu}$, $\mathrm{Cd}$ and $\mathrm{Pb}$, in environmental samples, J. Anal. At. Spectrom., 30 (2015) 1386-1394.

[214] A.H. Panhwar, T.G. Kazi, H.I. Afridi, S.A. Arain, K.D. Brahman, M.S. Arain, A new solid phase microextraction method using organic ligand in micro-pipette tip syringe system packed with modified carbon cloth for preconcentration of cadmium in drinking water and blood samples of kidney failure patients, Spec-trochim. Acta Part A, 138 (2015) 296-302.

[215] T. Da, S. Saçmacı, A. Ülgen, S. Kartal, A solid phase extraction procedure for the determination of $\mathrm{Cd}(\mathrm{II})$ and $\mathrm{Pb}(\mathrm{II})$ ions in food and water samples by flame atomic absorption spectrometry, Food Chem., 174 (2015) 591-596.

[216] M. Babazadeh, R. Hosseinzadeh-Khanmiri, J. Abolhasani, E. Ghorbani-Kalhor, A. Hassanpour, Solid phase extraction of heavy metal ions from agricultureal samples with the aid of a novel functionalized magneticmetal-organicframe-work, RSC Adv., 5 (2015) 19884-19892.

[217] O.M. Kalfa, Ö. Yalçınkaya, A.R. Türker, Synthesis of nano B2O3/TiO2 composite material as a new solid phase extractor and its application top reconcentration and separation of cadmium, J. Hazard. Mater., 166 (2009) 455-461.

[218] R. Sitko, P. Janik, B. Feist, E. Talik, A. Gagor, Suspended aminosilanized graphene oxide nanosheets for selective preconcentration of lead ions and ultrasensitive determination by electrothermal atomic absorption spectrometry, ACS Appl. Mater., 6 (2014) 20144-20153.

[219] M.C. Sneed, R.C. Brasted, C.V. King, Comprehensive inorganic chemistry, J. Electrochem. Soc., 103 (1956) 83.

[220] K.P. Lisha, T. Pradeep, Towards a practical solution for removing inorganic mercury from drinking water using gold nanoparticles, Gold Bull., 42 (2009) 144-152.

[221] I. Ojea-Jiménez, X. López, J. Arbiol, V. Puntes, Citrate-coated gold nanoparticles as smart scavengers for mercury(II) removal from polluted waters, ACS Nano, 6 (2012) 2253.

[222] M.P. Watts, V.S. Coker, S.A. Parry, R.A.D. Pattrick, R.A.P. Thomas, R. Kalin, J.R. Lloyd, 
Biogenic nano-magnetite and nano-zero valent iron treatment of alkaline $\mathrm{Cr}(\mathrm{VI})$ leachate and chromite ore processing residue, Appl. Geochem., 54 (2015) $27-42$.

[223] C. Shan, Z. Ma, M. Tong, J. Ni, Removal of Hg(II) by poly(1-vinylimidazole)-grafted $\mathrm{Fe}_{3} \mathrm{O}_{4} @ \mathrm{SiO} 2$ magnetic nanoparticles, Water Res., 69 (2015) 252260.

[224] M.E. Mahmoud, M.S. Abdelwahab, A.E.H. Abdou, Enhanced removal of lead and cadmium from water by $\mathrm{Fe}_{3} \mathrm{O}_{4}$-cross linked-O-phenylenediamine nanocomposite, Sep. Sci. Technol., 51 (2016) 237-247.

[225] L. Giraldo, A. Erto, J.C. Moreno-Piraján, Magnetite nanoparticles for removal of heavy metals from aqueous solutions: Synthesis and characterization, Adsorp., 19 (2013) 465-474.

[226] Y.Q. Tan, M. Chen, Y.M. Hao, High efficient removal of $\mathrm{Pb}(\mathrm{II})$ by amino-functionalized $\mathrm{Fe}_{3} \mathrm{O}_{4}$ magnetic nano-particles, Chem. Eng. J., 191 (2012) 104-111.

[227] J. Shi, H.Y. Li, H.G. Lu, Zhao, X.W. Use of Carboxyl Functional Magnetite Nanoparticles as Potential Sorbents for the Removal of Heavy Metal Ions from Aqueous Solution. J. Chem. Eng. Data 2015, 60, 2035-2041.

[228] S.D. Pan, H.Y. Shen, Q.H. Xu, J. Luo, M.Q. Hu, Surface mercapto engineered magnetic $\mathrm{Fe}_{3} \mathrm{O}_{4}$ nanoadsorbent for the removal of mercury from aqueous solutions, J. Colloid Interface Sci., 365 (2012) 204 212.

[229] S. Christian, E. Robin, Z. Robert, F. Artur, K. Hauke, W. Christopher, O. Johannes, M. JanPhilip, S. Theo, N. Kornelius, Polymer-assisted self-assembly of superparamagnetic iron oxide nanoparticles into well-defined clusters: Controlling the collective magnetic properties, Langmuir ACS J. Surf. Colloids, 30 (2014) 11190-11196.

[230] J. Yang, B. Hou, J. Wang, X. Huang, Nanomaterials for the Removal of Heavy Metals from Wastewater, Nanomaterials, 9 (2019) 424

[231] O’Carroll D., Sleep B., Krol M., Boparai H., Kocur C. Nanoscale zero valent iron and bimetallic particles for contaminated site remediation, Adv. Water Resour., 51 (2013) 104-122.

[232] T. Liu, Z.L. Wang, Y. Sun, Manipulating the morphology of nanoscale zero-valent iron on pumice for removal of heavy metals from wastewater, Chem. Eng. J., 263 (2015) 55-61.

[233] Z. Zhen, H.Z. Wei, L.W. Li, X.X. Hua, Synchronous Treatment of Heavy Metal Ions and Nitrate by Zero- valent Iron, Huan Jing Ke Xue, 30 (2009) 775-779.

[234] S.M. Seyedi, H. Rabiee, S.M.S. Shahabadi, S.M. Borghei, Synthesis of Zero-valent Iron Nanoparticles via Electrical Wire Explosion for Efficient Removal of Heavy Metals: Water, Clean-Soil Air Water, 45 (2016) 1600139.

[235] W. Wei, Y. Hua, S. Li, W. Yan, W.X. Zhang, Removal of $\mathrm{Pb}(\mathrm{II})$ and $\mathrm{Zn}(\mathrm{II})$ using lime and nanoscale zero-valent iron (nZVI): A comparative study, Chem. Eng. J., 304 (2016) 79-88.

[236] S. Tighadouini, S. Radi, M. Bacquet, S. Degoutin, M. Zaghrioui, S. Jodeh, I Warad, Removal efficiency of $\mathrm{Pb}$ (II), $\mathrm{Zn}$ (II), Cd (II) and $\mathrm{Cu}$ (II) from aqueous solution and natural water by ketoenol-pyrazole receptor functionalized silica hybrid adsorbent, Sep. Sci. Technol., 52 (2017) 608-621.

[237] S. Radi, S. Tighadouini, M. Bacquet, S. Degoutin, Y. Garcia, New hybrid material based on a silicaimmobilised conjugated $\beta$-ketoenol-bipyridine receptor and its excellent $\mathrm{Cu}$ (II) adsorption capacity, Anal. Method., 8 (2016) 6923-6931.

[238] S. Radi, S. Tighadouini, M. Bacquet, S. Degoutin, J-P Dacquin, D. Eddike, M. Tillard, Y. Mabkhot, $\beta$-Ketoenol tethered pyridine and thiophene: synthesis, crystal structure determination and its organic immobilization on silica for efficient solid-liquid extraction of heavy metals, Molecul., 21(2016) 888-900. doi: 10.3390/molecules21070888.

[239] S. Radi, S. Tighadouini, M. Bacquet, S. Degoutin, B. Revel, M. Zaghrioui, Quantitative removal of $\mathrm{Zn}$ (II) from aqueous solution and natural water using new silica-immobilized ketoenol-pyridine receptor, J. Environ. Chem. Eng., 3 (2015)17691778. 